\title{
Omega-3 Fatty Acids, Inflammation and Angiogenesis: Nutrigenomic Effects as an Explanation for Anti-Atherogenic and Anti-Inflammatory Effects of Fish and Fish Oils
}

\author{
Marika Massaro ${ }^{a, b}$ Egeria Scoditti ${ }^{a, b} \quad$ Maria Annunziata Carluccio ${ }^{a, b}$ \\ Maria Rosa Montinari ${ }^{b}$ Raffaele De Caterina ${ }^{a, c}$ \\ ${ }^{a}$ CNR Institutes of Clinical Physiology, Pisa and Lecce, ${ }^{b}$ University of Lecce, Ecotekne, Lecce, and \\ 'Chair of Cardiology, 'G. d'Annunzio' University, Chieti, Italy
}

\section{Key Words \\ Omega-3 fatty acids $\cdot \mathrm{n}-3$ fatty acids $\cdot$ Adhesion molecules • Endothelium - Endothelial activation - Atherosclerosis . Cyclooxygenase-2 2 Plaque angiogenesis $\cdot$ Plaque rupture}

This series of investigations configures a clear example of nutrigenomics, i.e. how nutrients may affect gene expression, ultimately affecting a wide spectrum of human diseases.

Copyright $\odot 2007$ S. Karger AG, Basel

\begin{abstract}
Atherosclerosis is a dynamic process with inflammatory aspects playing a considerable pathogenetic role. In this process, the vascular endothelium is the key regulator of vascular function, promoting the maintenance of vascular homeostasis or the progression towards vascular disease. In the past 30 years, the dietary intake of omega-3 (n-3) polyunsaturated fatty acids - mainly derived from fish - has emerged as an important way to modify cardiovascular risk through beneficial effects on all stages of atherosclerosis. This review specifically focuses on the modulating effects of n-3 fatty acids on molecular events involved in early and late atherogenesis, including effects on endothelial expression of adhesion molecules, as well as pro-inflammatory and proangiogenic enzymes. By accumulating in endothelial membrane phospholipids, omega-3 fatty acids have been shown to decrease the transcriptional activation of several genes through a decreased activation of the nuclear factor- $\kappa B$ system of transcription factors. This occurs secondary to decreased generation of intracellular reactive oxygen species.
\end{abstract}

\section{KARGER}

Fax +41613061234

E-Mail karger@karger.ch

www.karger.com
(C) 2007 S. Karger AG, Basel

1661-6499/08/0012-0004\$24.50/0

Accessible online at:

www.karger.com/jnn
Omega-3 fatty acids have recently emerged as an example of nutrients able to modulate the expression of genes involved in inflammation and atherosclerosis. Their ability to influence such processes is therefore a good example of nutrigenomics. This review summarizes the evidence to this regard. Since a description of the molecular events underlying endothelial changes in atherosclerosis is important for an understanding of the mode of action of these nutrients, a short review of current concepts of inflammation and atherosclerosis gives the background to place their genomic effect in context.

\section{Inflammation in Atherosclerosis}

Atherosclerosis is currently regarded as a dynamic process arising from functional inflammatory changes in the endothelium of conduit arteries [1]. Here the vascular endothelium, no longer regarded as the passive lining of 
blood and lymphatic vessels, is a dynamic organ involved in metacrine, paracrine, and endocrine functions [2]. Located at the interface between the circulation and the vessel wall, the endothelium 'senses' changes in hemodynamic forces and blood-borne signals, and reacts by synthesizing and releasing vasoactive substances with anti-thrombotic, vasodilating and anti-atherogenic properties to maintain vascular homeostasis (fig. 1). However, with the persistence of damaging stimuli, such as high blood pressure, high levels of atherogenic lipoproteins, high glucose, high insulin, high homocysteine or products of cigarette smoking, this balance is disrupted and the vasculature, through a dynamic change in the endothelium, becomes susceptible to atheroma formation [3].

In its initial stages, atherosclerosis is characterized by the recruitment, in the wall of conduit arteries, of selected populations of white blood cells, especially monocytes and some T lymphocytes, and, secondly, by the gradual accumulation of lipids and extracellular matrix in the arterial intima, which becomes no longer the virtual space occurring in normal arteries. Monocytes attracted in the intima accumulate lipid droplets first intracellularly (foam cells) and later extracellularly, due to their apoptosis, resulting in the formation of a lipid core. The endothelium and the underlying matrix (fibrous cap) for long time during atherosclerosis progression prevent the content of the highly thrombogenic lipid core from entering in contact with circulating blood. The sudden rupture of this collagen layer, from the outside or, as recently appreciated, from the inside, due to the rupture of vasa vasorum penetrating in the intima or, in a minority of cases, a condition of endothelial erosion, transform this slow process into an acute situation due to the sudden development of thrombosis (fig. 2) [4]. When this occurs in a coronary artery, the ischemic necrosis of the depending myocardium produces the symptoms of an acute coronary syndrome, i.e. acute myocardial infarction or unstable angina.

Since monocyte recruitment into the intima of large arteries is specific for atherosclerosis as compared to other forms of leukocyte-endothelial interactions, it was hypothesized that these localized monocyte-endothelium interactions reflect specific molecular changes in the adhesive properties of the endothelial surface, due to the endothelial surface expression of specific endothelium-leukocyte adhesion molecules (ELAMs) ('atheroELAMs'). The first such protein, originally identified in the rabbit hypercholesterolemic model, is vascular cell adhesion molecule (VCAM)-1, a member of the immunoglobulin superfamily. The ligand for VCAM-1 is a het-

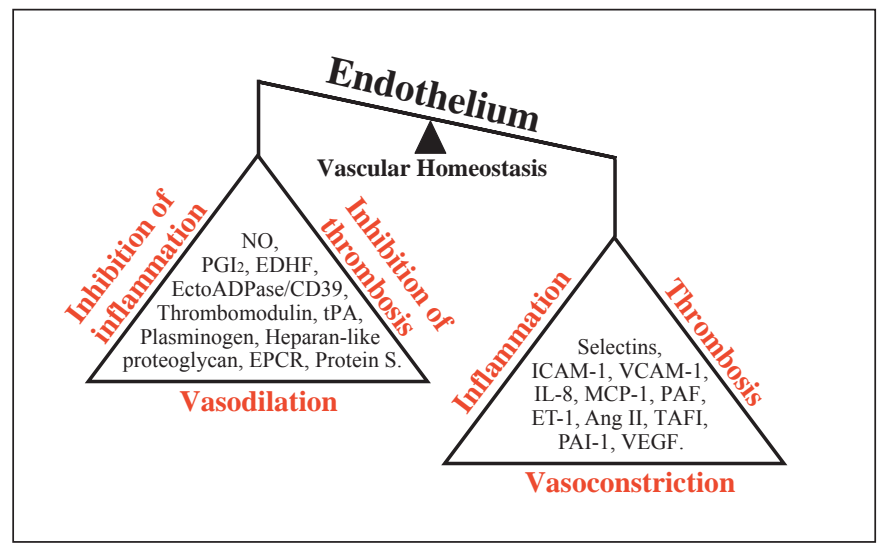

Fig. 1. Endothelial homeostatic derangements in atherosclerosis. Endothelium-derived factors act in concert to appropriately control vasoconstriction, smooth muscle proliferation, thrombosis, inflammation, coagulation and fibrinolysis. Endothelial dysfunctions, defined as the loss of any of these balanced functions, promote atherosclerosis. $\mathrm{NO}=$ Nitric oxide; $\mathrm{PGI}_{2}=$ prostacyclin; $\mathrm{EDHF}=$ endothelium-derived hyperpolarizing factor; $\mathrm{tPA}=$ tissue-type plasminogen activator; EPCR = endothelial cell protein C receptor; IL-8 = interleukin-8; MCP-1 = monocyte chemoattractant protein-1; ET-1 = endothelin-1; Ang II = angiotensin II; $\mathrm{TAFI}=$ thrombin-activatable fibrinolysis inhibitor; $\mathrm{PAF}=$ platelet activating factor; PAI-1 = plasminogen activator inhibitor-1; ICAM-1 = intercellular adhesion molecule-1; VCAM-1: vascular cell adhesion molecule-1; VEGF = vascular endothelial growth factor.

erodimeric integrin receptor, very late antigen 4 (VLA4), whose leukocyte selectivity of expression, on monocytes and lymphocytes, but not on neutrophils, can explain the selectivity of monocyte recruitment in early atherogenesis [5]. Endothelial cells express VCAM-1 early during cholesterol feeding in the rabbit, before the appearance of macrophages/foam cells in the intima of developing fatty streaks, in a temporal pattern consistent with its pathogenetic role in lesion development. Pathophysiologically relevant stimuli for VCAM-1 expression in atherogenesis include minimally oxidized low-density lipoproteins (LDL) or beta-very-low-density lipoproteins (VLDL), the advanced glycation end-products (AGEs) associated with diabetes, and perhaps lipoprotein (Lp)(a), homocysteine, elevated in homocystinuria and in subtler forms of congenital or acquired enzyme defects in homocysteine biosynthetic pathways, and possibly also high glucose and high insulin, occurring in diabetes and insulin resistance, respectively. In addition to these humoral stimuli, the endothelial gene expression of VCAM-1 also responds to hemodynamic forces, potentially explaining the localization of atherosclerosis in particular sites of 


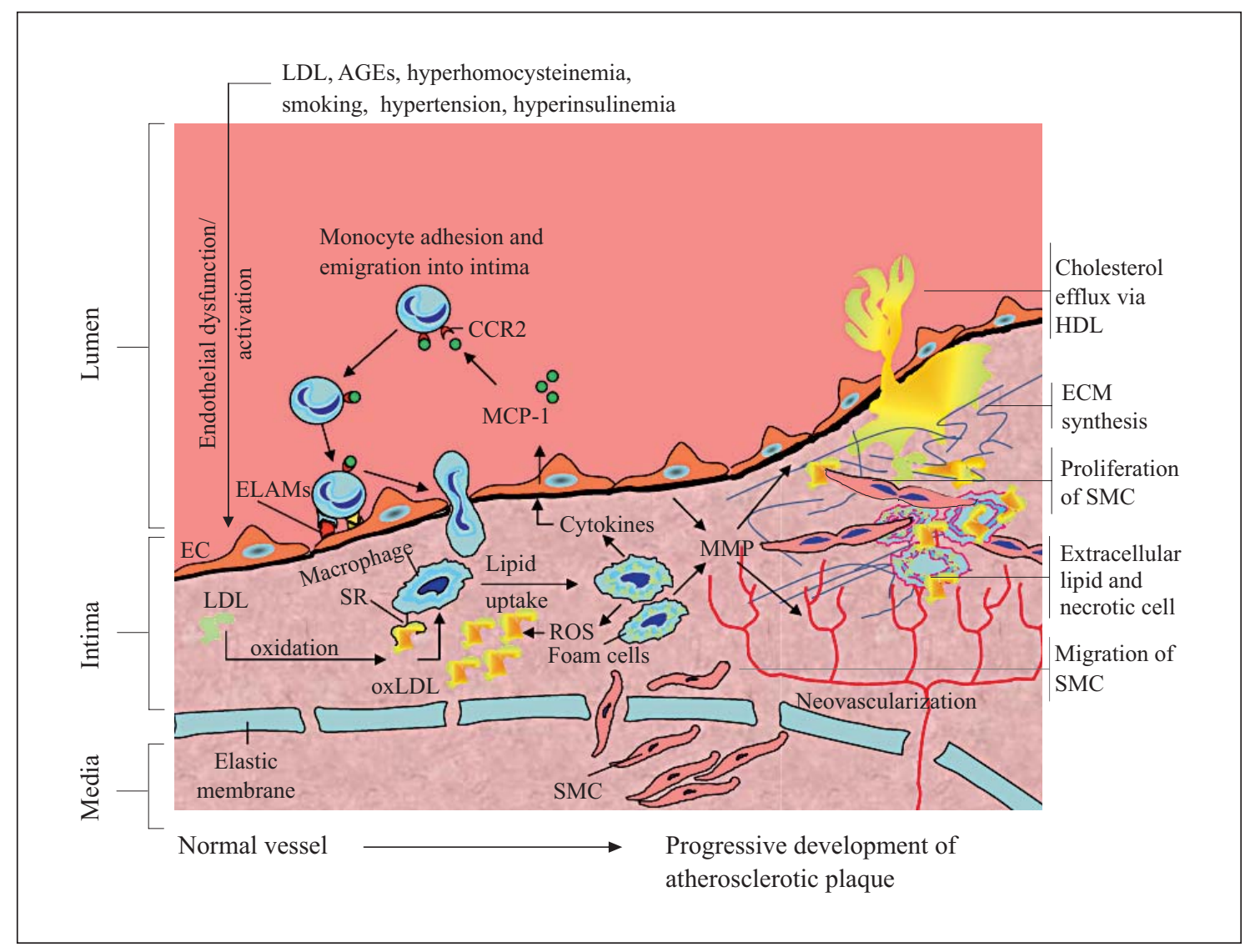

Fig. 2. Cellular and molecular events leading to atherosclerotic plaque formation. The illustration schematizes steps in the recruitment of mononuclear phagocytes into the nascent atherosclerotic plaque, and some of the functions of the endothelium and of macrophages in the mature atheroma. The steps are depicted in an approximate time sequence proceeding from left to right. When endothelial cells undergo inflammatory activation, they increase their expression of various leukocyte adhesion molecules, such as vascular cell adhesion molecule-1, which have a primary role in monocyte attraction. Once adherent to the activated endothelial layer, monocytes diapedese between intact endothelial cells to penetrate into the tunica intima. This directed migration requires a chemoattractant gradient, provided by various chemokines, including monocyte chemoattractant protein-1 (MCP-1) interacting with its $\mathrm{C}-\mathrm{C}$ chemokine receptor-2 (CCR2). Once resident in the intima, monocytes acquire characteristics of the tissue macrophage. In particular, they express scavenger re-

the arterial vasculature (for a general review on these issues, see [6]). A causal role of VCAM-1 in atherosclerosis is shown by the fact that the expression of a hypomorphic variant of VCAM-1, due to a partial knock-out of the molecule, protects against atherosclerosis in the LDL receptor knockout mouse model [7]. ceptors, which bind modified lipoproteins (modified by oxidation or glycation), a process that gives rise to arterial 'foam cells'. Macrophages serve many functions related to atherosclerosis and its complications, by secreting pro-inflammatory cytokines and growth factors that amplify the local inflammatory response in the lesion and promote the migration and proliferation of smooth muscle cells (SMC) into the intima, as well by producing reactive oxygen species (ROS), which contribute to the oxidation of lowdensity lipoproteins (LDL). Furthermore, activated macrophages play a key role in the thrombotic complications of atherosclerosis by producing matrix metalloproteinases (MMP), which degrade extracellular matrix and weaken the fibrous cap, or sustain neovascularization induced by local hypoxia. These fragile neovessels may then undergo rupture and cause intraplaque hemorrhages. Finally, macrophages can die, mostly by apoptosis, producing the so-called 'necrotic core' of the atherosclerotic lesion.

Once adhered, monocytes transmigrate, through the action of chemotactic stimuli also deriving from the activated endothelium, into the intima, the innermost layer of the arterial wall, where, upon internalization of modified lipoproteins, they become macrophages able to secrete proinflammatory cytokines, which contribute to maintaining a state of vascular inflammation, further 




Fig. 3. Formation of neovessels. Angiogenesis occurs as an orderly series of events: (1) diseased or injured (hypoxic) tissues produce and release angiogenic growth factors (VEGF, cytokines, angiopoietin-1, etc.), that diffuse into the surrounding tissues; (2) angiogenic growth factors bind to specific receptors located on the endothelial cells. The endothelial cells then become activated, and signals are sent from the cell surface to the nucleus; (3) endothelial cells then begin to produce new molecules, including MMP, which degrade the basement membrane surrounding the

augmenting the expression of adhesion molecules, chemoattractants and macrophage-activating factors, thus initiating a vicious circle leading to lesion progression (fig. 2). Later on, the production of matrix metalloproteinases (MMP) by the same macrophages as well as by endothelial cells may promote the erosion of the collagen layer of the fibrous plaque and ultimately lead to plaque rupture (fig. 2) [8].

Stability of the atherosclerotic plaque is indeed thought to reflect the balance and interplay of various dynamic factors, including endothelial dysfunction, the proliferation of smooth muscle cells (SMC), which are mainly responsible for the synthesis of collagen, and the degradation of collagen and other elements of the extracellular matrix by MMP. diseased vessels; (4) the endothelial cells begin to divide (proliferation), and then to migrate through the dissolved basement membrane towards the diseased tissue; (5) specialized molecules, such as the integrin $\alpha_{V} \beta_{3}$, serve as hooks to pull the sprouting new vessel forward. Tie-1 $=$ Tyrosine kinase with immunoglobulin and epidermal growth factor homology domains; Flk1/KDR = fetal liver kinase-1/kinase insert domain-containing receptor; $\mathrm{MMP}=$ matrix metalloproteinase $\mathrm{PGI}_{2}=$ prostacyclin; $\mathrm{TXA}_{2}=$ thromboxane $\mathrm{A}_{2}$.

The much sought-after prevention of acute coronary events requires therefore interventions that affect such cellular and molecular mechanisms leading to the slow formation of atherosclerotic lesions, as well as precipitating plaque rupture.

\section{Inflammatory Angiogenesis as a Promoter of Plaque Growth and Instability}

An increasing body of experimental and pathology data suggests that angiogenesis - the sprouting of new capillaries from pre-existing blood vessels (fig. 3) - may contribute to the initiation and progression of atherosclerosis [9]. The adventitial layer of human arteries normal-

J Nutrigenet Nutrigenomics 2008;1:4-23 
ly contains a microvascular network, termed vasa vasorum, that delivers oxygen and nutrients to the outer layers of the arterial wall. In contrast to the adventitia and, occasionally, the outer media, the inner media and the intima of normal large arteries usually do not contain capillaries $[10,11]$. However, during the progression of atherosclerosis, largely immature neo-microvessels penetrate into the media and the thickened intima (fig. 2) in more than $40 \%$ of lesions, initially stimulated by local hypoxia and then instigated by the inflammatory processes within the plaque $[10,11]$. The possibility that such neovasculature plays a role in plaque growth and destabilization was first hypothesized by Winternitz et al. [12] and Geiringer [13] in the late 1930s and 1940s, respectively, and partially demonstrated by Barger et al. [14] in the mid-1980s through the finding that 'plaque malignant neovascularization' in atherosclerotic coronary artery segments preferentially originates from the adventitial vasa vasorum, contrary to the intima of healthy segments of the same vessel, where there is no apparent angiogenesis. Later on, several reports have pointed out that plaque neo-angiogenesis might contribute to plaque instability, showing a positive association between the neovascularization in the intima and the media on the one hand, and symptomatic carotid occlusive disease on the other $[15,16]$, as well as between the density of coronary adventitial vessels reaching the intima and the extent of lumen stenosis [17]. Furthermore, it has been recently reported that the number of vasa vasorum is increased up to 2 -fold in vulnerable plaques and up to 4 -fold in ruptured plaques compared with stable plaques with severe luminal narrowing [18]. The entrance of neo-vessels into the intimal space from the adventitia occurs specifically at breakpoints in the medial layer, below sites of early necrotic core formation, following a typical maturation sequence: the neo-vessels first divide as they approach the core with secondary and tertiary branches, but while microvessels close to the medial wall are well formed, being accompanied by surrounding SMC, the intimal vessels near the lumen appear immature and therefore less functional, being too small to conduct adequate blood flow to ischemic tissues, and more prone to rupture [18]. A similar pattern occurs in the vessels of proliferative diabetic retinopathy, where the intimal vessels are mechanically weak and more prone to bleed [19]. Since these weak microvessels are often accompanied in their development by a recruitment of T helper cells [20], it has been also hypothesized that the $\mathrm{T}$ cells release of interferon (IFN) $-\gamma$ may inhibit SMC proliferation and therefore actively contribute to the absence of SMC in perfo- rating neovessels [21]. Furthermore, their augmented expression of endothelial leukocyte adhesion molecules suggests that they may actively recruit inflammatory cells into the lesions $[22,23]$, thus allowing the establishment of a positive feedback loop whereby inflammatory cells stimulate plaque angiogenesis, and new vessels promote further recruitment of inflammatory cells.

That these microvessels are functionally important in atherogenesis and its complications is also illustrated by the ability of angiogenesis inhibitors, such as angiostatin and TNP-470, to reduce angiogenesis and inhibit the development of lesions in apoE knockout mice [24], as well as by the observation that a classical pro-angiogenic stimulus, such as vascular endothelial growth factor (VEGF), potently promotes lesion development $[25,26]$.

\section{Role of COX-2 as Potential Regulator of Inflammatory} Angiogenesis and Plaque Instability

Due to the ability of prostanoids to orchestrate the complex neovascularization process [27], the proinflammatory enzyme cyclooxygenase (COX)-2 is now regarded as a critical inducer of angiogenesis [28]. Prostanoids include prostaglandin $(\mathrm{PG}) \mathrm{D}_{2}, \mathrm{PGF}_{2 \alpha}$, prostacyclin $\left(\mathrm{PGI}_{2}\right)$, and thromboxane (TX) $\mathrm{A}_{2}$, and their biosynthesis involves 3 sequential enzyme-catalyzed steps (fig. 4): (1) agonist-induced phospholiphase activation, leading to the release of arachidonic acid from membrane phospholipid pools; (2) cyclooxygenase (COX)-catalyzed oxygenation of the free fatty acid to generate the cyclic endoperoxide $\mathrm{PGH}_{2}$, and (3) enzymatic rearrangement of $\mathrm{PGH}_{2}$ structure to yield one of several bioactive derivatives. While the first 2 steps are shared by virtually all human cell types, the expression of downstream prostanoid synthases displays considerable cell type specificity [29].

Prostanoids mediate angiogenesis through multiple mechanisms (fig. 4) including: (1) the induction of VEGF production [30]; (2) the stimulation of endothelial cell sprouting, migration and tube formation [31-33]; (3) the enhancement of endothelial cell survival, through the upregulation of the anti-apoptotic protein $B$ cell lympho$\mathrm{ma}(\mathrm{Bcl})-2[34]$ and the activation of phosphatidylinositol (PI)3-kinase (K)-Akt pathway [35, 36]; (4) the upregulation of MMP-2 [37, 38] and MMP-9 [39], which are required for vascular invasion; (5) the promotion of angiogenic functions of the $\alpha_{v} \beta_{3}$ integrin $[40,41]$; (6) the activation of the epidermal growth factor receptor (EGFR), causing downstream angiogenic events [42], and (7) the decreased production of the endogenous angiogenesis inhibitor interleukin (IL)-12 [43]. 
Several reports have demonstrated the presence of both mRNA and protein for COX-2 in macrophages and SMC of atherosclerotic plaques, as well as of COX-1 and COX-2 in the endothelium of both atherosclerotic and healthy vessels $[44,45]$, thus suggesting a potential pathogenetic role for COX-2 activity. Furthermore, the finding of a co-localization of COX-2, MMP-9 and membrane type (MT)-1 MMP in the endothelial lining of vasa vasorum in human atherosclerotic aortas suggests a COX-2mediated promotion of plaque angiogenesis [46].

Besides contributing to plaque neovascularization [47], several other mechanisms have been hypothesized by which COX-2 inhibition may prevent atherothrombosis. COX-2 directly contributes to plaque instability, favoring the MMP release in macrophages, as observed in vitro [48] and in vivo in atherosclerotic lesions obtained from patients with symptomatic carotid artery disease, where the simultaneous overexpression of functionally coupled COX-2, PGE synthase and MMP has been reported [49]. Secondly, prostaglandins exert potent actions on vascular SMC, regulating contractility $[50,51]$, cholesterol metabolism [52], and proliferation [53]. The increased expression of COX-2 may thus contribute to the accumulation of lipids in lesional SMC, besides macrophages, favoring the formation of SMC and macrophage-derived foam cells within the atheroma. Conversely, anti-proliferative and anti-migratory actions of COX-2 products on SMC [53] contribute to the evolution of a lesion toward a SMC-depleted and macrophage-enriched plaque phenotype, and thus a more vulnerable plaque [54].

In spite of these well-documented pro-atherogenic functions [55], the usefulness to inhibit COX-2 activity is still controversial [56]. In murine models of atherosclerosis, treatment with selective COX-2 inhibitors has been reported to decrease, increase or have no impact on atherosclerosis [57-61]. These studies suggest that the role of COX-2 in atherosclerosis is complex and may vary with lesion stage or the animal model. A critical review of the experimental design of the studies so far reported reveals several plausible explanations for the variability of the results. Studies reporting a beneficial effect of selective COX-2 inhibition on atherosclerosis mostly looked at the impact of treatment on early atherosclerotic lesion formation, whereas studies showing no effect evaluated the impact on advanced lesions. Thus, one can hypothesize that COX-2 contribution in atherogenesis varies temporally according to the stage of atherosclerotic lesion formation.

Nutrigenomics of Omega-3 Fatty Acids



Fig. 4. COX-2 induces angiogenesis via multiple pathways. COX-2 converts arachidonic acid to prostaglandin $\mathrm{H}_{2}\left(\mathrm{PGH}_{2}\right)$, which is then converted to thromboxane $\mathrm{A}_{2}\left(\mathrm{TXA}_{2}\right)$, prostaglandin $\mathrm{E}_{2}$ $\left(\mathrm{PGE}_{2}\right)$, prostacyclin $\left(\mathrm{PGI}_{2}\right)$, prostaglandin $\mathrm{D}_{2}\left(\mathrm{PGD}_{2}\right)$ and prostaglandin $\mathrm{F}_{2 \alpha}\left(\mathrm{PGF}_{2 \alpha}\right)$ by tissue-specific prostanoid synthases. Each prostanoid promotes specific angiogenic steps and mediators. References specific to each mechanism depicted are reported in parentheses. $\mathrm{EC}=$ Endothelial cell(s); VEGF = vascular endothelial growth factor; $\alpha_{\mathrm{v}} \beta_{3}=$ vascular integrin; $\mathrm{MMP}=$ matrix metalloproteinase; $\mathrm{Bcl}-2=\mathrm{B}$-cell lymphoma-2, an antiapoptotic factor; Akt/protein kinase $(\mathrm{PK}) \mathrm{B}=\mathrm{a}$ survival signal pathway; c-fos $=$ a proto-oncogene

\section{Cardiovascular Protection by Omega-3 Fatty Acids}

\section{Omega-3 Fatty Acids: Structure, Source and Metabolism}

Polyunsaturated fatty acids (PUFA) are organic acids naturally containing more that one double bonds in their aliphatic chain. It is the number and position of double bonds within the hydrocarbon chain that gives PUFA their name and their physical and physiological properties. Biologically relevant families of PUFA are the omega -3 and the omega -6 fatty acids. In the omega- 3 fatty acids the terminal double bond is on the third carbon (from the methyl end of the hydrocarbon chain, fig. 5). In this respect, they are structurally distinct from the more commonly encountered omega- 6 family in which the terminal double bond is on the sixth carbon. The simplest members of omega- 6 and omega- 3 families are linoleic $(18: 2 \mathrm{n}-6)$ and $\alpha$-linolenic (18:3n-3) acids, respectively (fig. 5). Since the double bond in the $n-3$ or $n-6$ position cannot be inserted into fatty acids by animal enzymes (but only by vegetable $\Delta 12$ - and $\Delta 15$-desaturase), linoleic and $\alpha$-linolenic acids represent 'essential nutrients' for mammals, as was shown in the late 1920s when omega-3

J Nutrigenet Nutrigenomics 2008;1:4-23 


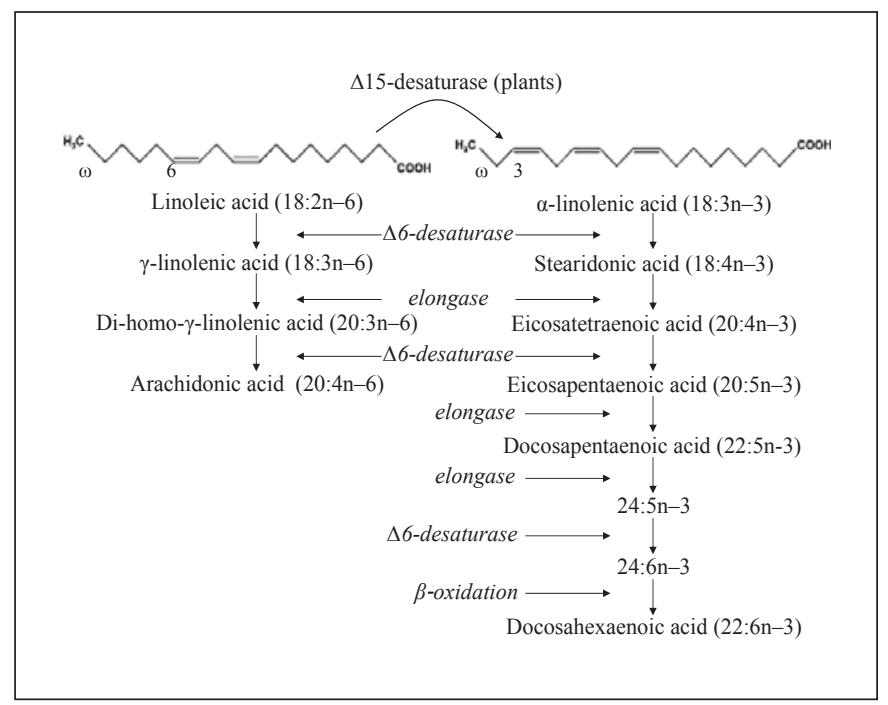

Fig. 5. Chemical structure and pathway of conversion of linoleic and $\alpha$-linolenic acid into longer derivative.

and omega- 6 deprivation experiments performed in rats identified the 'essential fatty acid deficiency' syndrome as similar to other 'essential nutrient deficiencies' syndromes $[62,63]$. It is estimated that minimum human requirements for these fatty acids are 1 and $0.2 \%$ of daily energy intake for omega- 6 and omega- 3 fatty acids, respectively [64]. Because they are synthesized by plants, plant tissues and oils are good sources of linoleic and $\alpha$ linolenic acids. Green plant tissues are especially rich in $\alpha$-linolenic acid, which typically comprises $55 \%$ of the fatty acids present in green vegetables. However, such tissues are not rich in fat, and therefore this source does not make a sufficient contribution to the minimum intake of this fatty acid in humans. In contrast, some plant oils such as corn, sunflower and rapeseed oil, can make a significant contribution to the intakes of these fatty acids and of their longer derivatives. In fact, although mammalian cells cannot synthesize linoleic and $\alpha$-linolenic acids, they can metabolize them by further desaturation and elongation (fig. 5). Linoleic acid can be converted into $\gamma$-linolenic acid $(18: 3 n-6)$ by $\Delta 6$-desaturase and then $\gamma$-linolenic acid can be elongated (by elongase) to dihomo- $\gamma$-linolenic acid (20:3n-6). Dihomo- $\gamma$-linolenic acid can be desaturated further by $\Delta 5$-desaturase to finally yield arachidonic acid (20:4n-6). Using the same series of enzymes, $\alpha$-linolenic acid is converted into eicosapentaenoic acid (20:5n-3, EPA) (fig. 5). The further conversion of EPA into docosahexaenoic acid (22:6n-3, DHA) involves a first addition of two carbon atoms to
Table 1. EPA and DHA contents of various seafood and other foods [from refs. 145, 146]

\begin{tabular}{lll}
\hline Food & EPA, g/100 g & DHA, g/100 g \\
\hline Cod & 0.08 & 0.01 \\
Trout & 0.23 & 0.09 \\
Plaice & 0.16 & 0.04 \\
Canned crab & 0.47 & 0.08 \\
Haddock & 0.05 & 0.01 \\
Herring & 0.51 & 0.11 \\
Mackerel & 0.71 & 0.12 \\
Prawns & 0.06 & $<0.01$ \\
Mussels & 0.41 & 0.02 \\
Canned sardines & 0.89 & 0.10 \\
Salmon & 0.50 & 0.40 \\
Roast beef & 0.02 & 0.02 \\
Roast lamb & 0.03 & 0.04 \\
Roast pork & 0.01 & 0.02 \\
Chicken & 0.01 & 0.02 \\
Venison & 0.04 & 0.09 \\
\hline
\end{tabular}

form docosapentaenoic acid (22:5n-3, DPA), two further carbons to produce $24: 5 n-3$, and a desaturation to form $24: 6 n-3$. The removal of two carbons from $24: 6 n-3$, by limited $\beta$-oxidation, yields DHA [65].

In mammals, these pathways of desaturation and elongation occur mainly in the liver, where $\Delta 6$-desaturase constitutes the rate-limiting enzyme [66]. The preferred substrate for $\Delta 6$-desaturase is $\alpha$-linolenic acid [66]; however, being linoleic acid much more prevalent than $\alpha$-linolenic acid in most human diets, metabolism of n-6 fatty acids is quantitatively more important. Furthermore, recent studies have revealed that the conversion of $\alpha$-linolenic acid into its longer-chain derivatives is, altogether, scarcely efficient in adult humans, especially in males [67, 68]. This means that the direct intake of the long-chain derivatives EPA and DHA is by far the easiest way to increase the concentration of such fatty acids in human tissues.

A good dietary source of long-chain n-3 fatty acids is fish. Fish can be classified into 'lean' fish, that store fat as triacylglycerols in the liver (e.g. cod), or 'fatty' fish that store fat as triacylglycerols in the flesh (e.g., mackerel, herring, salmon and tuna). The oil obtained from the flesh of fatty fish or the liver of lean fish is termed 'fish oil', and has the distinctive characteristic of being rich in long-chain omega-3 fatty acids. Different oily fish (and therefore different fish oils) contain different amounts of EPA and DHA (table 1), and this seems to be related to the dietary habits and metabolic characteristics $[69,70]$ 
of the fish as well as to season, water temperature and phase in the breeding cycle [71].

Epidemiologic and Experimental Evidence for Atheroprotective Effects of Omega-3 Fatty Acids

Over the past three decades, a great deal of epidemiologic evidence has been accumulated supporting cardiovascular benefits of fish and fish oil intakes [72]. Historically, first observations were done in Greenland, Northern Canada and Alaska, where Inuit populations on traditional dietary habits showed much lower-than-predicted cardiovascular mortality, despite their high fat intake [73-75]. The protective component was suggested to be the omega- 3 fatty acids consumed in very high amounts (5-15 g/day) as a result of the regular intake of fish or fish-eating mammals, such as seals [76]. Afterwards, similar observations were done also for Eastern populations such as the Japanese [77] and the Chinese [78] consuming traditional diets rich in oily fish. In Western populations with a generally low intake of omega-3 fatty acids, both protective effects [79-83] and no effects [84-87] of omega-3 fatty acids on cardiovascular disease have been reported. This can be explained by the difficulty in maintaining constant feeding habits in a population during long observational studies and by the competing influence of other dietary principles, including saturated or other unsaturated fatty acids.

The epidemiologic association between dietary omega -3 fatty acids and protection from cardiovascular disease can be attributed, at least in part, to a decreased extent of atherosclerosis. Many experimental studies have clearly demonstrated that omega-3 fatty acids favorably affect many of the factors involved in the development of atherosclerosis (table 2). Numerous animal studies have shown decreased atherosclerosis in animals treated with omega-3 fatty acids (reviewed in [88-90]). Furthermore, evidence has been obtained about such effects in humans, through autopsy studies in Alaskan natives (consuming high amounts of fish-derived products) and non-natives, mostly consuming Western-type diets. In the study by Newman et al. [75], the magnitude of difference in fatty streak development appears larger in younger age groups, suggesting an effect of diet mainly in the early events leading to fully developed atherosclerotic lesions. Furthermore, a study of omega- 3 fatty acids supplementation after coronary bypass surgery indicated that such treatment significantly reduces vein graft stenosis [91], a process which may be regarded as an accelerated form of atherosclerosis.

Nutrigenomics of Omega-3 Fatty Acids
Table 2. Effects of omega-3 polyunsaturated (PUFA) fatty acids on factors involved in the development of atherosclerosis

\begin{tabular}{ll}
\hline Pro-atherosclerotic factor & $\begin{array}{l}\text { Effect of } \\
\text { omega-3 PUFA }\end{array}$ \\
\hline
\end{tabular}

Plasma triacylglycerol concentration

(fasting and postprandial)

Production of chemoattractants

Production of growth factors

Cell surface expression of adhesion molecules

Production of cytokines

Blood pressure

Endothelial relaxation

Thrombosis

Cardiac arrhythmias

Atherosclerotic plaque stability

\section{Modulation of Endothelial-Leukocyte Interactions} and Endothelial Activation by Omega-3 Fatty Acids

Our own research has disclosed potential mechanistic explanations for the preventive or therapeutic use of omega-3 fatty acids. We hypothesized that omega-3 fatty acids modulate atherogenesis by affecting processes of early atherosclerotic development leading to the formation of fatty streaks. As illustrated above, such processes are mostly comprised under the name of 'endothelial activation'. We used human adult saphenous vein endothelial cells or human umbilical vein endothelial cells activated by cytokines, as an in vitro model of these early steps in atherogenesis, first assessing the effects of various fatty acids on the surface expression of endothelial leukocyte adhesion molecules, and subsequently characterizing mechanisms and functional relevance of such effects. In particular, we observed that DHA, when added to cultured endothelial cells hours to days before the stimulation with cytokines, early enough to allow a significant incorporation in cell membrane phospholipids, significantly inhibited events connected with endothelial activation, including the expression of adhesion molecules such as VCAM-1, E-selectin and, to a lesser extent, ICAM1 , after stimulation with virtually any stimulus able to elicit the coordinated expression of such genes [6, 92]. The inhibition of adhesion molecule expression occurred in a range of DHA concentrations compatible with nutritional supplementation of this fatty acid to a normal Western diet, occurred at any time point after the appearance of cytokine effect, modifying the kinetics of surface expression of adhesion molecules, and was strictly related in magnitude to the extent of incorporation into total cell 
lipids. Indeed, the extent of VCAM-1 inhibitory effect paralleled the incorporation of DHA in cellular phospholipids, and was inversely related to the content of omega6 fatty acids $[6,92]$. This effect was not limited to the expression of transmembrane molecules involved in leukocyte recruitment, but appeared to occur also for other cytokine-activated products, such as the soluble proteins IL- 6 and IL-8, involved in either the amplification of the inflammatory response (IL-6), or in the specific chemoattraction for granulocytes (IL-8), and was accompanied by a functional counterpart, i.e., a reduced monocyte or monocytoid cell adhesion to cytokine-activated endothelium $[6,92]$.

Experiments following the fate of ${ }^{14} \mathrm{C}$-labelled DHA into cell phospholipids showed a significant incorporation of DHA into the phosphatidyl ethanolamine pool, i.e., in a specific and not particularly abundant phospholipid pool, likely in the inner plasma membrane, and therefore in a possibly strategic position to alter intracellular signal transduction pathways. To investigate the mechanism of DHA action on endothelial activation, we analyzed the effects of various fatty acids (differing in chain length, number, position - omega-3 vs. omega- 6 vs. omega-9 - and cis/trans configuration of the double bonds) on the stimulated expression of VCAM-1. We observed the lack of any effect by saturated fatty acids, and an increase of potency of PUFA in parallel with the number of unsaturations, independently of the chain length and configuration (cis vs. trans) of the double bond [93]. In the same experimental conditions we also measured the intracellular cytokine-induced production of reactive oxygen species (ROS) believed to act as critical second messengers in the signaling pathway leading to the activation of adhesion molecule expression and hence to endothelial activation. In parallel with the modulation of VCAM-1 expression, a reduction of intracellular ROS release was also evident, proportional to the number of double bonds in the fatty acid chain [94]. This suggested that a property related to fatty acid peroxidability (the presence of multiple double bonds), usually regarded as a detrimental consequence of PUFA enrichment of cell membranes, is probably also directly related to the inhibition of ROS release/production, an event crucial for cell responsiveness to cytokines. Whether, however, PUFA protective effects occur through a direct quenching of free ROS on the double bonds or indirectly through the production of metabolically active oxidized products is still a matter of debate.

These data are not in contrast with the possibility that a product of omega-3 fatty acid oxidation inhibits cyto- kine-induced VCAM-1 expression through a peroxisome proliferators activated receptor- $\alpha$ (PPAR $\alpha)$-dependent mechanism, as observed by Sethi et al. [95]. PPARs are ligand-activated transcription factors belonging to the nuclear receptor superfamily, which also includes the steroid and thyroid hormone receptors [96]. Originally cloned in an attempt to identify the molecular mediators of peroxisome proliferation in the liver of rodents [97], after their identification also in endothelial cells [98] many experimental data have accumulated regarding their function as regulators of lipid and glucose metabolism and of inflammatory gene expression in vascular cells $[96,99]$. The PPAR family is comprised of three members, $\alpha, \gamma$ and $\beta / \delta$. PPAR $\alpha$ is found in tissues where fatty acid catabolism is important (the liver, the kidney, the heart, and the muscle), and regulates genes that are involved in lipid and lipoprotein metabolism [100]. PPAR $\alpha$ natural ligands include polyunsaturated fatty acids (DHA and EPA), oxidized phospholipids, lipoprotein lipolytic products and synthetic ligands such as fenofibrate and gemfibrozil clinically used to treat patients with elevated serum triglycerides [101]. PPAR $\gamma$, conversely, controls adipocyte differentiation and lipid storage [102]. PPAR $\gamma$ natural ligands are the prostaglandin D2 derivative 15 -deoxy- $\Delta 12,14$-prostaglandin $\mathrm{J} 2$ and forms of oxidized linoleic acid, 9- and 13(S)-hydroxyoctadecadienoic acid (HODE). PPAR $\beta / \delta$ is expressed in many tissues and like PPAR $\alpha$ plays a role in lipid metabolism by stimulating fatty acid oxidation in the heart and the skeletal muscle [103]. It is known that synthetic PPAR $\alpha$ agonists decrease the transcription of VCAM-1 and the adhesion of monocytes to cytokine-activated endothelial cells [104]. Sethi and coworkers [105] observed that oxidized EPA, activating PPAR $\alpha$, reduces cytokine- and LPS-induced NF- $\kappa \mathrm{B}$ activation, VCAM- 1 expression and the adhesion of monocytes in vivo. This effect was seen to occur in a PPAR $\alpha$-dependent fashion because oxidized EPA did not show any effect in LPS-treated PPAR $\alpha$-deficient mice [95].

\section{Modulation of Inflammatory Angiogenesis and Plaque Stability by Omega-3 Fatty Acids}

A recent study has disclosed a further potential role for omega-3 fatty acids in promoting a decrease in the risk of atherosclerotic plaques rupture in patients awaiting carotid endarterectomy [106]. In this study, plaques from patients taking fish oil featured a clear incorporation of omega-3 fatty acids into plaque lipids, and this correlated with a reduced macrophage infiltration and thicker fibrous caps compared with plaques from pa- 
Fig. 6. DHA inhibits endothelial cell tube formation. Human umbilical vein endothelial cells (HUVEC) were treated with $25 \mu \mathrm{mol} / \mathrm{l}$ docosahexaenoic acid (DHA) for $48 \mathrm{~h}$ and, after enzymatic detachment, plated on Matrigel-coated 48-well plates and stimulated with $20 \mathrm{ng} / \mathrm{ml}$ vascular endothelial growth factor (VEGF) plus 10 $\mathrm{ng} / \mathrm{ml}$ phorbol myristate acetate (PMA). After incubation at $37^{\circ} \mathrm{C}$ for $4 \mathrm{~h}$, cells showed tube formation. The quantification of tube formation was done by counting the number of branching points in microscopic photographs. The bar graph represents data from 3 independent experiments with two wells per condition and $2-3$ fields per well. ${ }^{*} \mathrm{p}<0.05$ vs. stimulated control.



Control

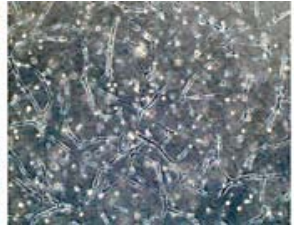

VEGF + PMA

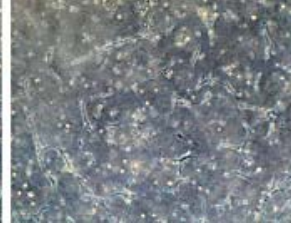

VEGF + PMA + DHA

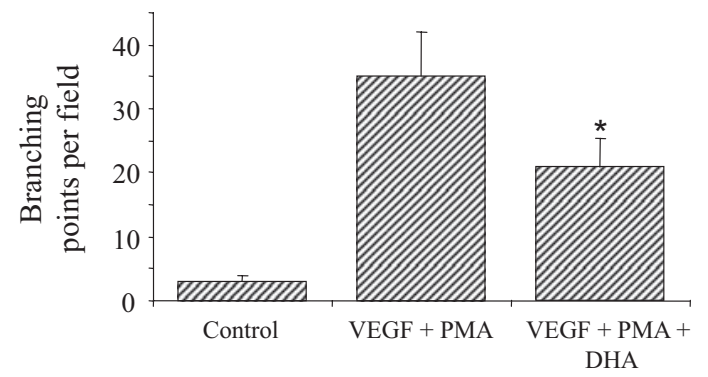

tients assuming sunflower oil-enriched control capsules [106]. In the attempt to find out the mechanistic basis of such plaque-stabilizing effect, an anti-angiogenic activity as well as a reduction of MMP release by omega-3 fatty acids might well be invoked. We specifically looked at the effects of omega-3 fatty acids on angiogenesis and MMP expression in atherosclerosis. Studies of this kind are found in the literature in the area of cancer and tumor angiogenesis, from which a number of paradigms are more and more nowadays transferred to cardiovascular medicine [9]. In the early 1990s, Rose and Connolly found that dietary omega-3 fatty acids inhibited the growth and development of metastases from transplanted MDA-MB-435 human breast cancer cells in the athymic nude mice [107]. The invasive potential of these cells, when evaluated in vitro, also appeared to be reduced when the cells were incubated with EPA and DHA [108]. The same authors subsequently expanded these results showing that the effect of DHA on tumor growth could be explained by the reduction of tumor angiogenesis (microvessel count) and the production of $\mathrm{PGE}_{2}$, known to affect the release of MMP [109]. In this study, the release of MMP was not assessed, but using similar cancer cell transplantation in the nude mice model, Suzuki et al. [110] later showed that the inhibition of lung metastases of a colon cancer cell line by EPA and DHA was associated with a reduced activity of MMP-9. Such a reduction in MMP-9 activity was also found by Harris et al. [111] in the uterus, the placenta and the liver of rats fed diets enriched with DHA. These authors explained their findings according to the known competition hypothesis of omega- 3 fatty acids with omega -6 fatty acids (mostly arachidonic acid) for being substrates for cyclooxygenase. This would have consequently changed the production of $\mathrm{PGE}_{2}$, thus in turn affecting MMP activity. Omega-3 fatty acids also negatively affect angiogenesis reducing the tumor production of VEGF [112] and the endothelial expression of the VEGF receptor Flk-1 [113].

The in vivo anti-angiogenic activity of omega- 3 fatty acids has been confirmed in in vitro models of angiogenesis by Kanayasu et al. [114] and Tsuji et al. [115], who separately tested bovine carotid artery endothelial cells treated with omega -3 fatty acids in different angiogenesis models. Similar results were confirmed in our laboratory using human umbilical vein endothelial cells (HUVEC). By performing 'Matrigel' assays, which allow to detect the formation of capillaries in a tri-dimensional collagen matrix, we observed that the exposure of HUVEC to DHA reduced the vascular endothelial tubelike formation induced by VEGF and phorbol-myristate acetate (PMA), as determined by the reduced number of branching points formed by DHA-treated HUVEC on the matrix surface (fig. 6). In agreement with what ob- 
Table 3. Comparison of COX-1 and COX-2

\begin{tabular}{lll}
\hline & COX-1 & COX-2 \\
\hline Locus & $9 \mathrm{q} 32-\mathrm{q} 33.3$ & $1 \mathrm{q} 25.2-\mathrm{q} 25.3$ \\
Size of gene & $22 \mathrm{~kb}$ & $8.3 \mathrm{~kb}$ \\
Number of exons & 11 & 10 \\
Size of mRNA & $2.8 \mathrm{~kb}$ & $4.6 \mathrm{~kb}$ \\
Coding nucleotides & 1,797 & 1,812 \\
Number of amino acids & 576 & 604 \\
$5^{\prime}$-Flanking region & no TATA box, GC-rich, Sp-1 & NF- $\mathrm{kB}$, NF-IL-6, AP-2, CRE, TATA box \\
3'-Untranslated region & $0.7 \mathrm{~kb}$ & $2 \mathrm{~kb}$, AUUUA-rich elements \\
Style of expression & constitutive & inducible \\
Size of protein & $69 \mathrm{kDa}$ & $71 \mathrm{kDa}$ \\
\hline
\end{tabular}

served by Jones et al. [116], we also observed an anti-angiogenic effect after cell treatment with NS-398, an inhibitor of COX-2 activity, thus further supporting the hypothesis of a pro-angiogenic role of COX-2 metabolites. This made the hypothesis plausible that DHA might exert an anti-angiogenic effect also reducing COX-2 expression.

\section{COX-2 Gene Expression: A Pivotal Role for NF- $\kappa B$}

There are two known isoforms of COX, COX-1 and -2 . The gene for COX-1, located on human chromosome 9, is approximately $22 \mathrm{~kb}$ in length with 11 exons, and is transcribed as a $2.8 \mathrm{~kb}$ mRNA. COX-1 is a glycoprotein of 576 amino acids with an apparent molecular mass of $69 \mathrm{kDa}$ (table 3). There are several putative transcriptional regulatory elements in the promoter region, including two Sp1 motifs, two activator protein (AP)-2 sites, a nuclear factor for interleukin-6 (NF-IL-6) motif, and a GATA site, but the lack of TATA box, linked to the high frequency of GC repeats, makes COX-1 a typical housekeeping gene [117]. It is indeed constitutively expressed in many tissue including the vascular endothelium, monocytes, platelets, renal collecting tubules and seminal vesicles [118]. The gene for COX-2, located on human chromosome 1, is approximately $8.3 \mathrm{~kb}$ long with 10 exons, and is transcribed as 4.6-, 4.0- and 2.8-kb mRNAs variants [119] (table 2). The gene structures of COX-1 and COX-2 demonstrate remarkable conservation of exon-intron junctions [118]. The differences between COX-1 and COX-2 genes are (a) the first intron in COX-1 is lost in COX-2, and (b) the introns in the COX-2 gene are shorter than those in the COX-1 gene. The largest exon in the COX-2 encodes the entire $3^{\prime}$-untranslated region (3'-UTR), containing 23 copies of the 'ATTTA' RNA instability element [120]. Se- quence analysis of the 5 '-flanking region has shown several potential transcription regulatory elements, including a TATA box, a nuclear factor (NF)-IL-6 motif, two AP-2 sites, three Sp1 sites, two NF- $\kappa$ B sites and a cyclic adenosine mono-phosphate response element (CRE) (fig. 6). However, only a limited number of elements, the CRE, the NF-IL- 6 and the NF- $\kappa$ B, are known to be critically involved in the regulation of the endothelial COX-2 gene expression [118].

NF- $\kappa \mathrm{B}$ comprises a family of redox-sensitive transcription factors recognized as critical regulators of the expression of many pro-inflammatory genes, such as those encoding for adhesion molecules (VCAM-1, ICAM1 and E-selectin), chemokines, cytokines, and enzymes producing inflammatory mediators, such as COX-2 [121]. Sequencing of the endothelial COX-2 promoter region has revealed the presence of two NF- $\kappa \mathrm{B}$ consensus sites [118], and their importance in COX-2 induction has been clearly shown by studies using deleted and site-mutated promoter constructs [118]. Active NF- $\mathrm{BB}$ complexes are dimers of various combinations of the Rel family poly-

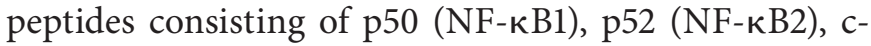
Rel, v-Rel, Rel A (p65), and Rel B [122]. In resting cells, NF- $\kappa \mathrm{B}$ is retained in the cytoplasm by binding to one of the inhibitory $\mathrm{I} \kappa B$ proteins $(\operatorname{I\kappa } B \alpha, \operatorname{I} \kappa B \beta, \operatorname{Ik} B \varepsilon, p 105$, and p100), which blocks the nuclear translocation of NF- $\kappa B$ [122]. NF- $\kappa B$ is activated in response to a wide variety of pro-inflammatory and pro-angiogenic stimuli each promoting the dissociation of ІкB through its phosphorylation, followed by ubiquitination and degradation (fig. 7). Thus, the unmasking of the nuclear localization sequence of NF- $\kappa \mathrm{B}$ allows NF- $\kappa \mathrm{B}$ to enter the nucleus and bind to $\kappa B$-regulatory elements [121]. The phosphorylation of I B is catalyzed by an IкB kinase (IKK) complex [122]. 


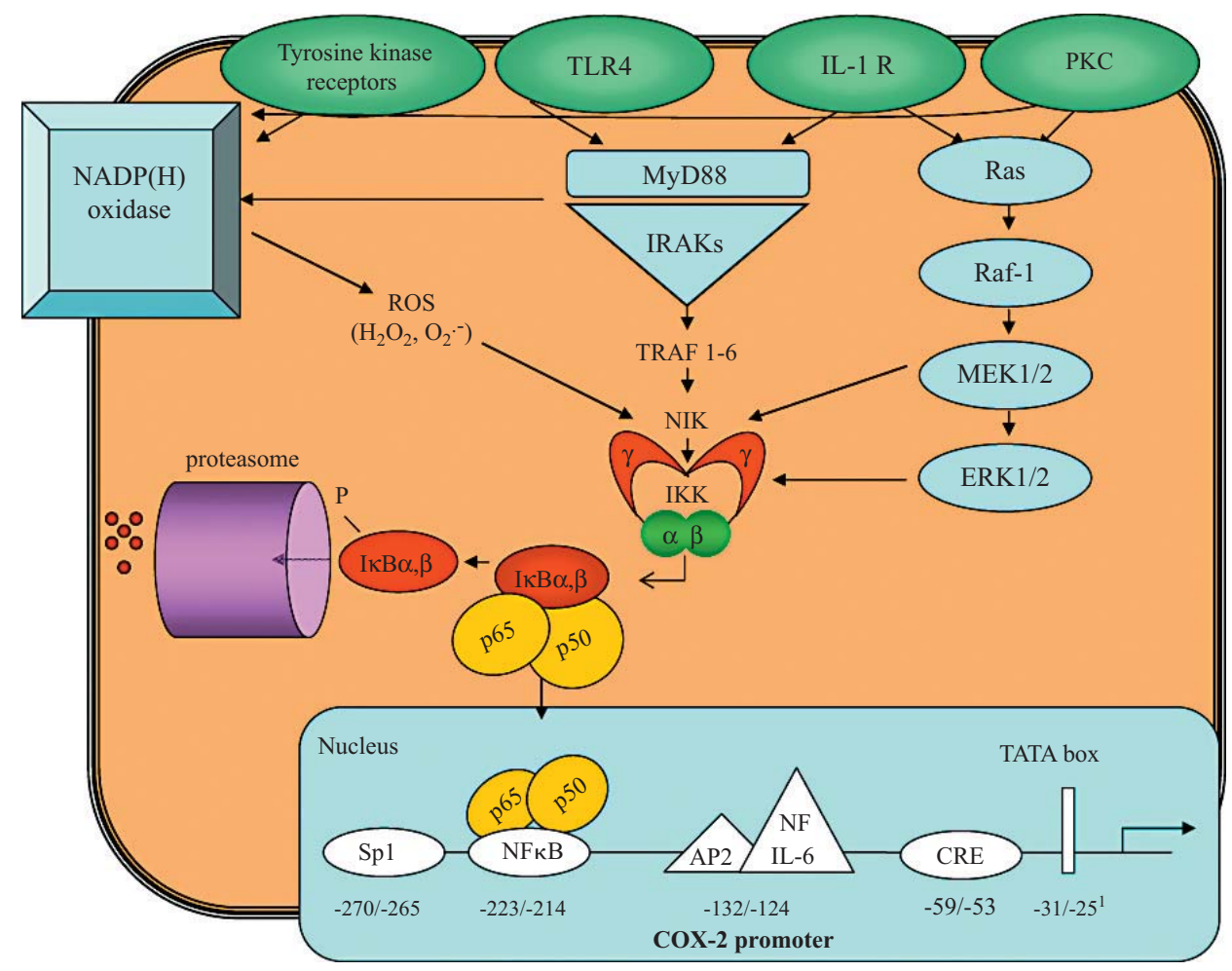

Fig. 7. A simplified scheme of signaling pathways leading to COX2 gene induction by NF- $\kappa$ B activation. The binding of growth factors, IL-1 or LPS to their respective receptors induces the activation of specific signaling pathways - including the production of reactive oxygen species (ROS) (including $\mathrm{H}_{2} \mathrm{O}_{2}$ ) through the activation of $\mathrm{NAD}(\mathrm{P}) \mathrm{H}$ oxidase, which leads to NF- $\mathrm{\kappa B}$-inducing kinase (NIK) activation, IкB kinase (IкB) degradation, and the nuclear translocation of p65-p50. In the nucleus, NF- $\kappa \mathrm{B}$, upon bind- ing to the respective consensus sequences, critically contributes to COX-2 and to the induction of other proinflammatory genes, such as VCAM-1, ICAM-1, MCP-1, etc. TLR4 = Toll-like receptor4; IL-1 R = IL-1 receptor; $\mathrm{PKC}=$ protein kinase C; MyD88 = myeloid differentiation factor; IRAK = IL-1 receptor-associated kinase; TRAF $=$ TNF receptor-associated factor; $\mathrm{AP}-2=$ activator protein-2; NF-IL-6 = nuclear factor for interleukin-6; CRE = cyclic adenosine monophosphate response element.
The core of IKK complex consists of a heterodimer of IKK $\alpha$ and IKK $\beta$, and two IKK- $\gamma$ subunits. IKK $\alpha$ and IKK $\beta$ mediate the phosphorylation of I $\mathrm{B}$, whereas IKK$\gamma$ links the core to the upstream signaling molecules (fig. 7) [122]. Also the activation of the IKK complex is dependent on phosphorylation, and multiple upstream kinases, some of which are redox-sensitive, have been suggested to act as IKK kinases [122].

Many agents that activate mitogen-activated protein kinases (MAPK) also induce an overproduction of ROS besides activating NF- $\kappa \mathrm{B}$, suggesting a cross-talk between these pathways (fig. 7). For example, IL-1 has been shown to induce COX-2 through a mechanism mediated by the activation of the extracellular signal-regulated kinases (ERKs), C-Jun N-terminal kinase/stress-activated protein kinase (JNK/SAPK) and p38 MAPK [123]. Lysophosphatidylcholine, a component of oxidized LDL, activates COX-2 expression by p38 MAP kinase activation, the proangiogenic transcription factors cAMP-responsive element-binding protein (CREB) and activating transcription factor (ATF)-1 [124]. Finally, phorbol myristate acetate (PMA), an activator of protein kinase $\mathrm{C}$ (PKC), induces COX-2 primarily through the activation of ERK1/2 [125]. However, the exact site of interference of 


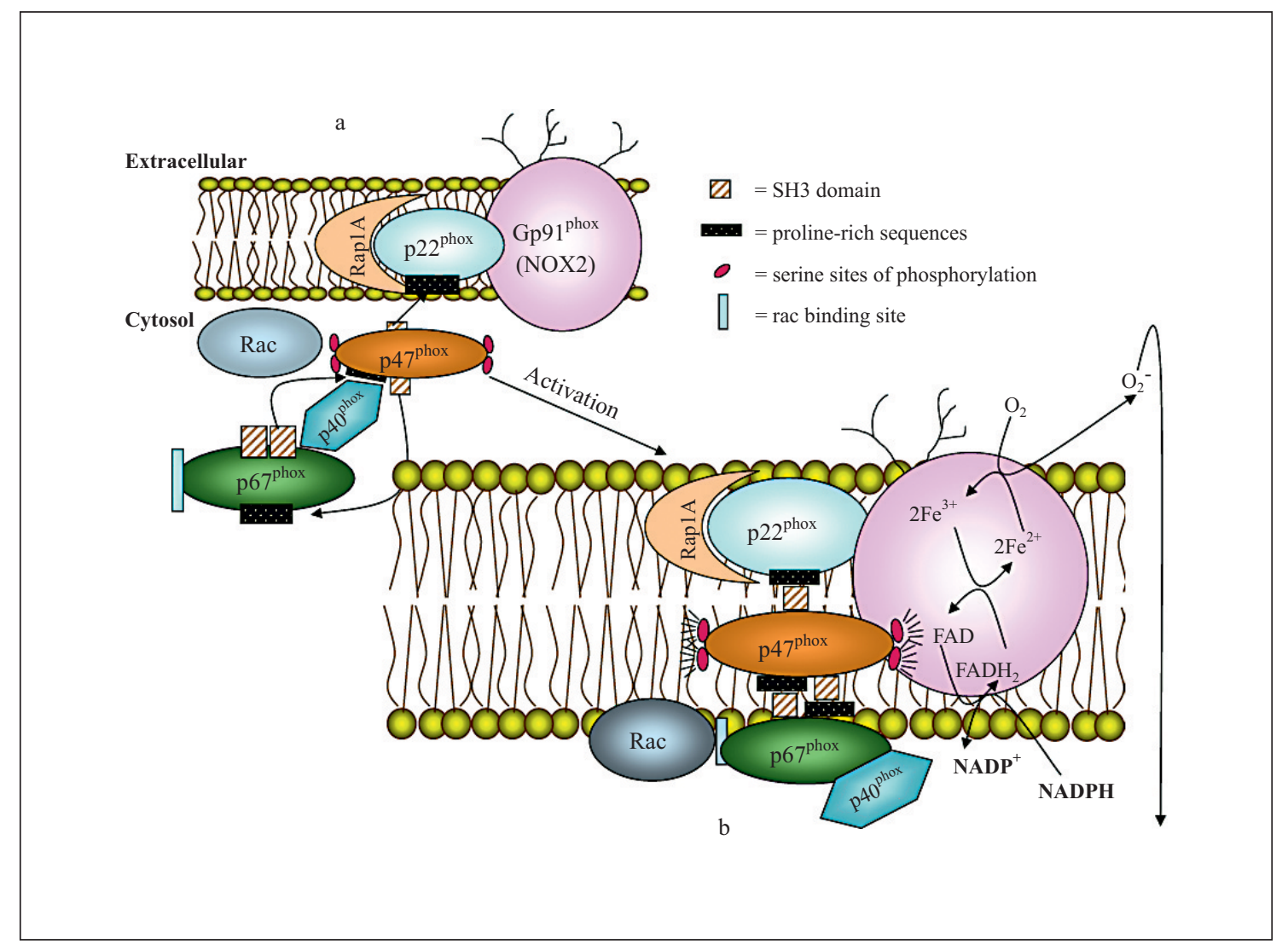

Fig. 8. A putative scheme of the $\mathrm{NAD}(\mathrm{P}) \mathrm{H}$ oxidase system in the vascular endothelium. Endothelial NAD $(\mathrm{P}) \mathrm{H}$ oxidase is composed of a membrane-bound component and a cytosolic moiety. gp91 phox (where phox is phagocyte oxidase) - also named Nox2


cytochrome $b_{558}$ and, together with the low-molecular-weight protein Rap1A, are located across the plasma membrane. The cytosolic components are $\mathrm{p} 40^{\text {phox }}, \mathrm{p} 47^{\text {hhox }}, \mathrm{p} 67^{\text {phox }}$, and Rac2. All the cytosolic subunits join the membrane-bound element when they are activated. The arrows indicate the protein-protein interac- tions among $\mathrm{NAD}(\mathrm{P}) \mathrm{H}$ oxidase components in the inactive and active states. During activation, one of the two SH3 domains of $\mathrm{p} 47^{\text {phox }}$ binds to a proline-rich sequence within the C-terminus of p22 ${ }^{\text {phox }}$. The other SH3 domain binds to a proline-rich sequence in p67phox. Moreover, the $\mathrm{SH} 3$ domain in the C-terminus of p6 $67^{\text {phox }}$ binds to a proline-rich sequence of the p47phox. P67phox contains a binding region for Rac, and $\mathrm{p} 40^{\text {phox }}$ can interact with the C-terminal proline-rich domain of $\mathrm{p} 47^{\text {phox }}$. The endothelial enzyme seems to be distributed for the $50 \%$ on plasma membrane and for the remaining $50 \%$ in a perinuclear position [141]. these MAPK activities along the pathway leading to NF$\kappa \mathrm{B}$ activation, as well as the site of interference with ROS production, likely triggered by the activation of nicotinamide adenine-dinucleotide(phosphate) $[\mathrm{NAD}(\mathrm{P}) \mathrm{H}]$ oxidase (fig. 7 and 8), is still elusive.

\section{Effects of Omega-3 Fatty Acids on Endothelial \\ COX-2 Expression}

The effect of omega- 3 fatty acids on COX-2 expression and activity in the vascular tissue has not been extensively studied, and the findings are not always in agreement. In the murine monocytic cell line RAW264.7, DHA
[126, 127], but not EPA [128], reduced the stimulated COX-2 expression. Similarly, results obtained using cultured endothelial cells have been variable. Gilbert et al. [129] showed that DHA treatment of bovine aortic endothelial cells potentiated COX-2 expression induced by PMA. Conversely EPA, but not DHA, greatly decreased IL-1 $\beta$-induced COX-2 expression in human microvascular endothelial cells [130]. Using both human saphenous and umbilical vein endothelial cells (HSVEC and HUVEC, respectively), we have recently observed that DHA treatment before IL-1 or PMA stimulation reduces COX-2 expression (see fig. 9a) and activity [131]. The reg- 
ulation of COX-2 expression involves both transcriptional and post-transcriptional events. Post-transcriptional regulation of COX-2 is dependent, in part, on 'UAAAU' instability sequences contained within the 3 '-untranslated region (UTR) of the encoding mRNA [132]. Having observed that DHA reduced COX-2 steady-state mRNA levels at Northern analysis, in the attempt to understand the site of DHA interference we first explored the possibility that DHA might increase COX-2 mRNA stability, setting up experiments to measure the messenger halflife in the presence of actinomycin-D as a transcription blocker. We observed no changes in COX-2 mRNA halflife when the endothelium was exposed to DHA, thus inferring a transcriptional effect for DHA. Accordingly, transient transfection experiments using full-length human COX-2 promoter constructs showed that DHA inhibited total promoter activity independent of the proinflammatory stimuli used. Furthermore, by the use of COX-2 promoter constructs either deleted or site-mutated at specific transcriptionally active sites, we observed that DHA inhibitory effect was abrogated only when promoter sequences were lacking, by deletion or site-mutation, functional NF- $\mathrm{kB}$ sites. This, together with the observed reduced activation of NF- $\kappa$ B (as assessed by electrophoretic mobility shift assay; EMSA) and the reduced nuclear translocation of $\mathrm{p} 65$, suggested an interference by DHA with the activated cytoplasmic signaling pathway leading to NF- $\kappa \mathrm{B}$ activation.

It is well known that omega-3 fatty acids, modifying lipid composition, alter membrane lipid microdomains, such as lipid rafts and caveolae, involved in the compartmentalization, modulation, and integration of cell signaling components $[133,134]$. In our experimental conditions, DHA accumulates into membrane phospholipids. Therefore, in the attempt to explore which molecular target(s) upstream of NF- $\kappa$ B was (were) affected by DHA, we first focused our attention on the $\mathrm{NADP}(\mathrm{H})$ oxidase, an enzyme system producing ROS involved in the activation of NF- $\kappa$ B by IL-1 [135], the assembly and activation of which is potentially sensitive to membrane phospholipid composition [136]. In resting conditions (fig. 8a), the NADPH oxidase complex consists of several subunits: two of them, p22 phox (phox stands for phagocytic oxidase) and glycoprotein (gp) $91^{\text {phox }}$ (NOX2 - NOX stands for NADPH oxidase in the endothelium), are integral membrane proteins, while the $\mathrm{p} 47^{\text {phox }}$ and $\mathrm{p} 67^{\text {phox }}$ subunits are located in the cytosol. Upon cell stimulation (fig. 8b), p47 $7^{\text {phox }}$ is phosphorylated and, in complex with $\mathrm{p} 67^{\text {phox }}$ and the small GTP-binding protein Rac, moves to the plasma mem-



Fig. 9. DHA reduces COX-2 expression by inhibiting NADPH oxidase and $\mathrm{PKC} \varepsilon$ activation. a The immunocytochemical analysis of the effect of docosahexaenoic acid (DHA) on the stimulated expression of cyclo-oxygenase(COX)-2 in endothelial cells. Human saphenous vein endothelial cells (HSVEC) were grown in 24 -well plates for $20 \mathrm{~h}$, and treated with $25 \mu \mathrm{mol} / \mathrm{l} \mathrm{DHA}$ for $48 \mathrm{~h}$ before stimulation with IL- $1 \alpha 10 \mathrm{ng} / \mathrm{ml}$ for $16 \mathrm{~h}$. After incubations, monolayers were fixed and immunostained with anti-COX2 monoclonal antibodies. Immunocytochemistry with a non-immune IgG, as a control, revealed no staining (not shown). A reduction of COX-2 expression occurs in cells pre-exposed to DHA (right column). b HSVEC were pretreated with $25 \mu \mathrm{mol} / \mathrm{l}$ DHA for $48 \mathrm{~h}$ and then stimulated with $10 \mathrm{ng} / \mathrm{ml} \mathrm{IL}-1 \alpha$ for $1 \mathrm{~h}$. Monolayers were then washed and loaded for $30 \mathrm{~min}$ with reduced $2^{\prime}, 7^{\prime}$ dichlorodihydrofluorescein diacetate (DCF). This is a non-polar compound that readily diffuses into the cells, where it is hydrolyzed by intracellular esterases to the nonfluorescent derivative, which being polar is trapped within the cells. In the presence of intracellular hydrogen peroxide $\left(\mathrm{H}_{2} \mathrm{O}_{2}\right)$ or some of its downstream products, this compound is oxidized to the highly fluorescent compound $2^{\prime}, 7^{\prime}$-dichlorofluorescein. The green fluorescence measured is therefore proportional to the $\mathrm{H}_{2} \mathrm{O}_{2}$ produced. DHA treatment reduces the fluorescence intensity and therefore, by inference, the production of reactive oxygen species (panel in the right column). c HSVEC were pretreated with $25 \mu \mathrm{mol} / 1 \mathrm{DHA}$ for $48 \mathrm{~h}$ and then stimulated with $10 \mathrm{ng} / \mathrm{ml} \mathrm{IL-} \alpha$ for $20 \mathrm{~min}$. Subcellular soluble and particulate (membrane) fractions were isolated and Western blots were performed with an antibody specific for $\mathrm{p} 47^{\text {phox }}$. Values are in units of optical density (OD). The blot depicted is representative of 2 similar ones. $\mathbf{d}$ HSVEC were pretreated with $25 \mu \mathrm{mol} / \mathrm{l} \mathrm{DHA}$ for $48 \mathrm{~h}$ and then stimulated with 10 nmol/l PMA for $20 \mathrm{~min}$. Subcellular soluble and particulate (membrane) fractions were isolated and Western blots were performed using anti-PKC $\varepsilon$ antibody. Values of PKC translocations are reported as units of OD at densitometric analysis. The blot is representative of 2 similar ones. Modified from Massaro et al. [131]. 


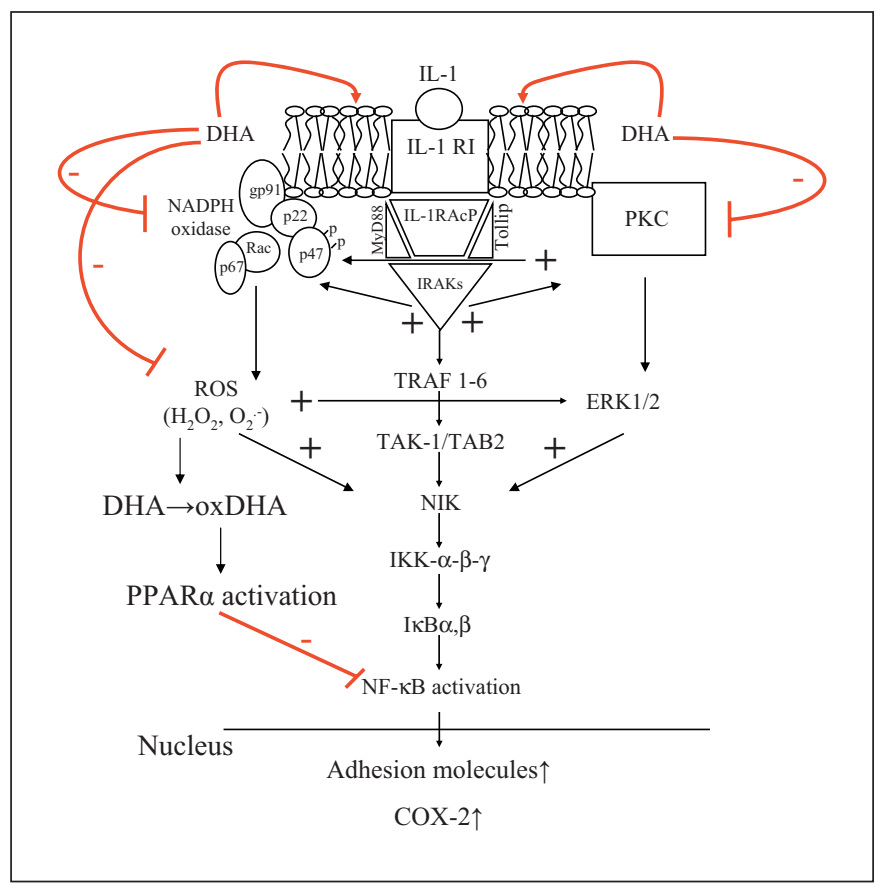

Fig. 10. Proposed integrative molecular model of dietary omega3 fatty acid interference with IL-1 signaling pathways, leading to adhesion molecules and COX-2 induction in endothelial cells. IL1 binds to the IL-1 receptor type I (IL-1RI), which heterodimerizes with the IL-1 receptor accessory protein (IL-1RAcP). The IL$1 \mathrm{R}$-associated kinases (IRAK) are then recruited and associated by the adapter proteins myeloid differentiation factor (MyD) 88 and Toll-interacting protein (Tollip). The signaling pathway also includes the production of reactive oxygen species (ROS, namely $\mathrm{H}_{2} \mathrm{O}_{2}$ ) through the activation of NAD $(\mathrm{P}) \mathrm{H}$ oxidase by IRAK activation, as well as the activation of $\mathrm{PKC}$, both contributing to nuclear factor $(\mathrm{NF})-\kappa \mathrm{B}$ activation. DHA, by interfering with the production of ROS (through the inhibition of p47phox translocation and/or the scavenging of ROS by its multiple double bonds), would prevent the formation of $\mathrm{H}_{2} \mathrm{O}_{2}$, thus limiting the entire downstream cascade leading to COX-2 gene expression. Furthermore, DHA reduces PKC $\varepsilon$ activation, thus inhibiting ERK1/2 activation, also leading to NF- $\mathrm{\kappa B}$ activation and COX-2 expression. Finally, cytokine-induced ROS could attack DHA and transform it into an oxidized derivative able to activate PPAR $\alpha$ and thereby further inhibit NF- $\kappa \mathrm{B}$ through a mechanism of trans-repression [142]. TRAF $=$ TNF receptor-associated factor; TAK- $1=$ TGF $\beta$ activated kinase 1 ; TAB-2 $=$ TAK1-binding protein 2 ; NIK $=$ NF$\kappa \mathrm{B}$-inducing kinase; IKK = I $\mathrm{B}$ kinase; PPAR $\alpha=$ peroxisomeproliferator-activated receptor. Modified from Massaro et al. [131].

brane to form the active enzyme complex [137]. We demonstrated that DHA leads to decreased p47phox membrane translocation, together with diminished $\mathrm{NAD}(\mathrm{P}) \mathrm{H}$ oxidase activity and intracellular ROS production (fig. 9b, c). Since PKCs, besides being implicated in NADPH oxidase activation, also mediate COX-2 expression [138], and since PKC $\varepsilon$ activity is specifically involved in the activation of NF- $\mathrm{\kappa B}$ by ERK1/2 induction [139], we next explored the possibility that PKCs could be another molecular switch affected by DHA. We monitored membrane translocation of the main PKC isoforms in endothelial cells stimulated by PMA and IL-1 in the presence of DHA. All such isoforms were activated by PMA, as demonstrated by their translocation to plasma membrane, but only the translocation of PKC $\varepsilon$ was reduced by DHA treatment (fig. 8d). We therefore concluded that DHA, possibly modifying the plasma membrane lipid composition and hence membrane microdomain organization, inhibits at least two molecular switches both involved in COX-2 expression, the activation of $\mathrm{NAD}(\mathrm{P}) \mathrm{H}$ oxidase and the activation of PKC $\varepsilon$. An integrative molecular model of dietary omega -3 fatty acids interference with IL-1 signaling pathway leading to adhesion molecules and COX-2 induction in endothelial cells is proposed in figure 10 .

\section{Conclusions and Perspectives}

The vascular endothelium plays a key role in the progression of cardiovascular disease as well as in the maintenance of solid cancer cell cords, orchestrating the neovascularization of atherosclerotic plaque and cancer tissue growth. On the other hand, omega- 3 fatty acids have emerged as an effective tool in the primary and secondary prevention of cardiovascular disease and some forms of cancer. Although they exert multiple actions [140], the transcriptional control of several endothelial pro-inflammatory genes, including those encoding for adhesion molecules, chemokines and other soluble cytokines in the endothelium, likely play an important role. The recent findings showing inhibition of COX- 2 expression and activity by omega -3 fatty acids allows a deeper understanding of the therapeutic potential of these nutrients, being COX-2 overexpression pathogenetically involved in different inflammatory/ degenerative diseases besides atherosclerosis (from rheumatoid arthritis to inflammatory bowel disease and, possibly, Alzheimer's disease). Far from being therefore only a source of energy and building blocks of our body tissues, omega-3 fatty acids appear therefore to finely tune the response of our genes to dangerous environmental challenges, by curbing physiological responses without abrogating them totally. By decreasing the endothelial responsiveness to pro-inflammatory, 
pro-atherogenic and pro-angiogenic stimuli, omega-3 fatty acids appear to impact molecular events not targeted by any other drugs or interventions, thus allowing us to propose their therapeutic role complementary to those of already implemented pharmacologic treatments in inflammatory diseases, including atherosclerosis. These are clear examples of nutrigenomics, i.e., how selected nutrients may affect the expression of our genes, allowing the interaction of genes with the environment in modulating the risk of human diseases.

\section{Acknowledgements}

We are indebted to all our former and current collaborators at the Laboratory for Thrombosis and Vascular Research at the Institute of Clinical Physiology of the Italian National Research Council (Consiglio Nazionale delle Ricerche, CNR) in Pisa, the Laboratory for Atherosclerosis Research at the CNR Institute of Clinical Physiology in Lecce, the Experimental Cardiology Laboratory at the 'G. d'Annunzio' Foundation in Chieti and the Laboratory of General Physiology at the University of Lecce for the experimental data on which most of the considerations here highlighted are based. We are also indebted to Peter Libby, MD, in whose laboratory the first observations of the nutrigenomic effects of DHA were made.

\section{References}

$\checkmark 1$ De Caterina R: Endothelial dysfunctions: common denominators in vascular disease. Curr Opin Clin Nutr Metab Care 2000;3: 453-467.

2 De Caterina R, Massaro M, Libby P: Endothelial functions and dysfunctions; in De Carerina R, Libby P (eds): Endothelial Dysfunction and Vascular Disease, Blackwall Publishing, 2007, pp 3-17.

- 3 Pearson TA, Mensah GA, Alexander RW, Anderson JL, Cannon RO 3rd, Criqui M, Fadl YY, Fortmann SP, Hong Y, Myers GL, Rifai N, Smith SC Jr, Taubert K, Tracy RP, Vinicor F: Markers of inflammation and cardiovascular disease: application to clinical and public health practice: a statement for healthcare professionals from the Centers for Disease Control and Prevention and the American Heart Association. Circulation 2003;107:499-511.

4 Ross R: Atherosclerosis: an inflammatory disease. N Engl J Med 1999;340:115-126.

5 De Caterina R, Gimbrone MA Jr: Leukocyteendothelial interactions and the pathogenesis of atherosclerosis; in Kristensen SD, Schmidt EB, De Caterina R, Endres S (eds): n-3 Fatty Acids - Prevention and Treatment in Vascular Disease. Berlin, Springer, 1995, pp 9-24.

6 De Caterina R, Cybulsky MA, Clinton SK, Gimbrone MA Jr, Libby P: Omega-3 fatty acids and endothelial leukocyte adhesion molecules. Prostagl Leukotr Ess Fatty Acids 1995;52:191-195.

7 Cybulsky MJ, Iiyama K, Li H, Zhu S, Chen M, Iiyama M, Davis VM, Gutierrez-Ramos J-C, Connelly PW, Milstone DS: A major role for VCAM-1, but not ICAM-1, in early atherosclerosis. J Clin Invest 2001;107:1255-1262.

8 Libby P: Vascular biology of atherosclerosis: overview and state of the art. Am J Cardiol 2003;91(suppl):3A-6A.

9 Moulton KS: Plaque angiogenesis: its functions and regulation. Cold Spring Harbour Symp Quant Biol 2002;67:471-482.
10 Kwon HM, Sangiorgi G, Ritman EL, McKenna C, Holmes DR Jr, Schwartz RS, Lerman A: Enhanced coronary vasa vasorum neovascularization in experimental hypercholesterolemia. J Clin Invest 1998;101: 1551-1556.

11 Vancov V: Structural basis of the microcirculation in the wall of arterial vessels. Bibl Anat 1973;11:383-388.

12 Winternitz M, Thomas R, LeCompte P: The Biology of Atherosclerosis. Springfield, Thomas, 1938.

13 Geiringer E: Intimal vascularization and atherosclerosis. J Pathol Bacteriol 1951;63: 201-211.

14 Barger AC, Beeuwkes R 3rd, Lainey LL, Silverman KJ: Hypothesis: Vasa vasorum and neovascularization of human coronary arteries: a possible role in the pathophysiology of atherosclerosis. N Engl J Med 1984;310: 175-177.

15 McCarthy MJ, Loftus IM, Thompson MM, Jones L, London NJ, Bell PR, Naylor AR, Brindle NP: Angiogenesis and the atherosclerotic carotid plaque: an association between symptomatology and plaque morphology. J Vasc Surg 1999;30:261-268.

16 Mofidi R, Crotty TB, McCarthy P, Sheehan SJ, Mehigan D, Keaveny TV: Association between plaque instability, angiogenesis and symptomatic carotid occlusive disease. $\mathrm{Br} \mathrm{J}$ Surg 2001;88:945-950.

17 Kumamoto M, Nakashima Y, Sueishi K: Intimal neovascularization in human coronary atherosclerosis: its origin and pathophysiological significance. Hum Pathol 1995;26:450-456.

18 Virmani R, Kolodgie FD, Burke AP, Finn AV, Gold HK, Tulenko TN, Wrenn SP, Narula J: Atherosclerotic plaque progression and vulnerability to rupture: angiogenesis as a source of intraplaque hemorrhage. Arterioscler Thromb Vasc Biol 2005;25:2054-2061.

19 Bonn D: Blocking angiogenesis in diabetic retinopathy. Lancet 1996;348:604.
20 Rankin EB, Yu D, Jiang J, Shen H, Pearce EJ, Goldschmidt MH, Levy DE, Golovkina TV, Hunter CA, Thomas-Tikhonenko A: An essential role of Th1 responses and interferon gamma in infection-mediated suppression of neoplastic growth. Cancer Biol Ther 2003; 2:687-693.

21 Chen C, Walterscheid JP: Plaque angiogenesis versus compensatory arteriogenesis in atherosclerosis. Circ Res 2006;99:787-789.

22 O'Brien KD, Allen MD, McDonald TO, Chait A, Harlan JM, Fishbein D, McCarty J, Ferguson M, Hudkins K, Benjamin CD, et al: Vascular cell adhesion molecule-1 is expressed in human coronary atherosclerotic plaques: implications for the mode of progression of advanced coronary atherosclerosis. J Clin Invest 1993;92:945-951.

23 O'Brien KD, McDonald TO, Chait A, Allen MD, Alpers CE: Neovascular expression of E-selectin, intercellular adhesion molecule1 , and vascular cell adhesion molecule- 1 in human atherosclerosis and their relation to intimal leukocyte content. Circulation 1996; 93:672-682.

24 Moulton KS, Heller E, Konerding MA, Flynn E, Palinski W, Folkman J: Angiogenesis inhibitors endostatin or TNP-470 reduce intimal neovascularization and plaque growth in apolipoprotein E-deficient mice. Circulation 1999;99:1726-1732.

25 Celletti FL, Hilfiker PR, Ghafouri P, Dake MD: Effect of human recombinant vascular endothelial growth factor165 on progression of atherosclerotic plaque. J Am Coll Cardiol 2001;37:2126-2130.

26 Celletti FL, Waugh JM, Amabile PG, Brendolan A, Hilfiker PR, Dake MD: Vascular endothelial growth factor enhances atherosclerotic plaque progression. Nat Med 2001; 7:425-429.

27 Gately S, Li WW: Multiple roles of COX-2 in tumor angiogenesis: a target for antiangiogenic therapy. Semin Oncol 2004;31:2-11. 
28 Leahy K, Koki A, Masferrer J: Role of cyclooxygenase in angiogenesis. Curr Med Chem 2000;7:1163-1170.

-29 Smith WL, Garavito RM, DeWitt DL: Prostaglandin endoperoxide $\mathrm{H}$ synthases (cyclooxygenases)-1 and -2. J Biol Chem 1996;271: 33157-33160.

30 Liu XH, Kirschenbaum A, Lu M, Yao S, Dosoretz A, Holland JF, Levine AC: Prostaglandin E2 induces hypoxia-inducible factor-1alpha stabilization and nuclear localization in a human prostate cancer cell line. J Biol Chem 2002;277:50081-50086.

31 Hahn GL, Polgar PR: Prostaglandin production in phenotypically distinct cultured bovine pulmonary artery endothelium. Atherosclerosis 1984;51:143-150.

32 Kuwashima L, Graeber J, Glaser BM: Stimulation of endothelial cell prostacyclin release by retina-derived factors. Invest Ophthalmol Vis Sci 1988;29:1213-1220.

-33 Murohara T, Horowitz JR, Silver M, Tsurumi Y, Chen D, Sullivan A, Isner JM: Vascular endothelial growth factor/vascular permeability factor enhances vascular permeability via nitric oxide and prostacyclin. Circulation 1998;97:99-107.

-34 Liu CH, Chang SH, Narko K, Trifan OC, Wu MT, Smith E, Haudenschild C, Lane TF, Hla $\mathrm{T}$ : Overexpression of cyclooxygenase- 2 is sufficient to induce tumorigenesis in transgenic mice. J Biol Chem 2001;276:1856318569.

-35 Arico S, Pattingre S, Bauvy C, Gane P, Barbat A, Codogno P, Ogier-Denis E: Celecoxib induces apoptosis by inhibiting 3-phosphoinositide-dependent protein kinase-1 activity in the human colon cancer HT-29 cell line. J Biol Chem 2002;277:27613-27621.

-36 Dimmeler S, Zeiher AM: Akt takes center stage in angiogenesis signaling. Circ Res 2000;86:4-5.

37 Callejas N, Casado M, Diaz-Guerra M, Bosca L, Martin-Sanz P: Expression of cyclooxygenase-2 promotes the release of matrix metalloproteinase-2 and -9 in fetal rat hepatocytes. Hepatology 2001;33:860-867.

38 Choi YA, Lee DJ, Lim HK, Jeong JH, Sonn JK, Kang SS, Baek SH: Interleukin-1beta stimulates matrix metalloproteinase-2 expression via a prostaglandin E2-dependent mechanism in human chondrocytes. Exp Mol Med 2004;36:226-232.

39 Pavlovic S, Du B, Sakamoto K, Khan KM, Natarajan C, Breyer RM, Dannenberg AJ, Falcone DJ: Targeting prostaglandin E2 receptors as an alternative strategy to block cyclooxygenase-2-dependent extracellular matrix-induced matrix metalloproteinase- 9 expression by macrophages. J Biol Chem 2006;281:3321-3328.
40 Dormond O, Bezzi M, Mariotti A, Ruegg C: Prostaglandin E2 promotes integrin alpha Vbeta 3-dependent endothelial cell adhesion, rac-activation, and spreading through cAMP/PKA-dependent signaling. J Biol Chem 2002;277:45838-45846.

41 Dormond O, Foletti A, Paroz C, Ruegg C: NSAIDs inhibit alpha V beta 3 integrin-mediated and Cdc42/Rac-dependent endothelial-cell spreading, migration and angiogenesis. Nat Med 2001;7:1041-1047.

42 Pai R, Soreghan B, Szabo IL, Pavelka M, Baatar D, Tarnawski AS: Prostaglandin E2 transactivates EGF receptor: A novel mechanism for promoting colon cancer growth and gastrointestinal hypertrophy. Nat Med 2002; 8:289-293.

43 Schwacha MG, Chung CS, Ayala A, Bland KI, Chaudry IH: Cyclooxygenase 2-mediated suppression of macrophage interleukin12 production after thermal injury. Am J Physiol 2002;282:C263-C270.

44 Schönbeck U, Sukkova G, Graber P, Coulter S, Libby P: Augmented expression of cyclooxygenase-2 in human atherosclerotic lesions. Am J Pathol 1999;155:1281-1291.

45 Stemme V, Swedenborg J, Claesson H, Hansson GK: Expression of cyclo-oxygenase-2 in human atherosclerotic carotid arteries. Eur J Vasc Endovasc Surg 2000;20:146-152.

46 Hong BK,Kwon HM, Lee BK, Kim D, Kim IJ, Kang SM, Jang Y, Cho SH, Kim HK, Jang BC, Cho SY, Kim HS, Kim MS, Kwon HC, Lee N: Coexpression of cyclooxygenase-2 and matrix metalloproteinases in human aortic atherosclerotic lesions. Yonsei Med J 2000;41: 82-88.

47 Bochkov VN, Philippova M, Oskolkova O, Kadl A, Furnkranz A, Karabeg E, Afonyushkin T, Gruber F, Breuss J, Minchenko A, Mechtcheriakova D, Hohensinner P, Rychli K, Wojta J, Resink T, Erne P, Binder BR, Leitinger N: Oxidized phospholipids stimulate angiogenesis via autocrine mechanisms, implicating a novel role for lipid oxidation in the evolution of atherosclerotic lesions. Circ Res 2006;99:900-908.

48 Corcoran M, Stetler-Stevenson W, DeWitt D, Whal L: Effect of cholera toxin and pertussis toxin on prostaglandin $\mathrm{H}$ synthase-2, prostaglandin $\mathrm{E}_{2}$ and matrix metalloproteinase production by human monocytes. Arch Biochem Biophys 1994;310:481-488.

49 Cipollone F, Prontera C, Pini B, Marini M, Fazia M, De Cesare D, Iezzi A, Ucchino S, Boccoli G, Saba V, Chiarelli F, Cucurullo F, Mezzetti A: Overexpression of functionally coupled cyclooxygenase- 2 and prostaglandin E synthase in symptomatic atherosclerotic plaque as a basis of prostaglandin $\mathrm{E}_{2-}$ dependent plaque instability. Circulation 2001;104:921-927.
50 Dorn GW 2nd, Becker MW, Davis MG: Dissociation of the contractile and hypertrophic effects of vasoconstrictor prostanoids in vascular smooth muscle. J Biol Chem 1992;267: 24897-24905.

51 Okon EB, Szado T, Laher I, McManus B, van Breemen C: Augmented contractile response of vascular smooth muscle in a diabetic mouse model. J Vasc Res 2003;40:520-530.

52 Wohlfeil ER, Campbell WB: 25-Hydroxycholesterol increases eicosanoids and alters morphology in cultured pulmonary artery smooth muscle and endothelial cells. Arterioscler Thromb Vasc Biol 1999;19:29012908.

53 Wong ST, Baker LP, Trinh K, Hetman M, Suzuki LA, Storm DR, Bornfeldt KE: Adenylyl cyclase 3 mediates prostaglandin E(2)-induced growth inhibition in arterial smooth muscle cells. J Biol Chem. 2001;276:3420634212.

54 Huttner JJ, Gwebu ET, Panganamala RV, Milo GE, Cornwell DC, Sharma HM, Geer JC: Fatty acids and their prostaglandin derivatives: Inhibitors of proliferation in aortic smooth muscle cells. Science 1977;197:289291.

55 Cipollone F and Fazia ML: COX-2 and atherosclerosis. J Cardiovasc Pharmacol 2006; 47(suppl 1):S26-S36.

56 Stacy ZA, Dobesh PP, Trujillo TC: Cardiovascular risks of cyclooxygenase inhibition. Pharmacotherapy 2006;26:919-938.

57 Bea F, Blessing E, Bennett BJ, Kuo CC, Campbell LA, Kreuzer J, Rosenfeld ME: Chronic inhibition of cyclooxygenase-2 does not alter plaque composition in a mouse model of advanced unstable atherosclerosis. Cardiovasc Res 2003;60:198-204.

58 Burleigh ME, Babaev VR, Oates JA, Harris RC, Gautam S, Riendeau D, Marnett LJ, Morrow JD, Fazio S, Linton MF: Cyclooxygenase-2 promotes early atherosclerotic lesion formation in LDL receptor-deficient mice. Circulation 2002; 105:1816-1823.

59 Burleigh ME, Babaev VR, Yancey PG, Major AS, McCaleb JL, Oates JA, Morrow JD, Fazio $S$, Linton MF: Cyclooxygenase- 2 promotes early atherosclerotic lesion formation in ApoE-deficient and C57BL/6 mice. J Mol Cell Cardiol 2005;21:21.

60 Pratico D, Tillmann C, Zhang ZB, Li H, FitzGerald GA: Acceleration of atherogenesis by COX-1-dependent prostanoid formation in low density lipoprotein receptor knockout mice. Proc Natl Acad Sci USA 2001;98:3358-3363.

61 Rott D, Zhu J, Burnett MS, Zhou YF, ZallesGanley A, Ogunmakinwa J, Epstein SE: Effects of MF-tricyclic, a selective cyclooxygenase-2 inhibitor, on atherosclerosis progression and susceptibility to cytomegalovirus replication in apolipoprotein-E knockout mice. J Am Coll Cardiol 2003;41:1812-1819. 
62 Burr G, Burr M: A new deficiency disease produced by rigid exclusion of fat free diet. J Biol Chem 1929;82:345-367.

63 Burr G and Burr M: On the nature of fatty acids essential in nutrition. J Biol Chem 1930;86:345-367.

64 Department of Health: Nutritional Aspect of Cardiovascular Disease: Report of the Cardiovascular Review Group. London, HMSO, 1994.

65 Sprecher H: Metabolism of highly unsaturated $n-3$ and n-6 fatty acids. Biochim Biophys Acta 2000;1486:219-231.

66 Yamazaki K, Fujikawa M, Hamazaki T, Yano $\mathrm{S}$, Shono T: Comparison of the conversion rates of alpha-linolenic acid $(18: 3(n-3))$ and stearidonic acid $(18: 4(n-3))$ to longer polyunsaturated fatty acids in rats. Biochim Biophys Acta 1992;1123:18-26.

67 Burdge G: Alpha-linolenic acid metabolism in men and women: nutritional and biological implications. Curr Opin Clin Nutr Metab Care 2004;7:137-144.

68 Burdge GC, Jones AE, Wootton SA: Eicosapentaenoic and docosapentaenoic acids are the principal products of alpha-linolenic acid metabolism in young men. Br J Nutr 2002;88:355-363.

69 Henderson R, Sargent J: Chain-length specificities of mitochondrial and peroxisomal beta-oxidation of fatty acids in livers of rainbow trout (Salmo gairdneri). Comp Biochem Physiol 1985;82B:79-85.

70 Linares F, Henderson R: Incorporation of 14C-labelled polyunsaturated fatty acids by juvenile turbot, Scophthalmus maximus (L.) in vivo. J Fish Biol 1991;38:335-347.

71 Tocher D, Sargent J: Effect of temperature on the incorporation into phospholipid classes and metabolism via desaturation and elongation of $n-3$ and $n-6$ polyunsaturated fatty acids in fish cells in culture. Lipids 1990;25: 435-442.

72 Wang C, Harris WS, Chung M, Lichtenstein AH, Balk EM, Kupelnick B, Jordan HS, Lau J: n-3 Fatty acids from fish or fish-oil supplements, but not alpha-linolenic acid, benefit cardiovascular disease outcomes in primary- and secondary-prevention studies: a systematic review. Am J Clin Nutr 2006;84:517.

73 Dyerberg J, Bang HO, Stofferson E, Moncada S, Vane JR: Eicosapentaenoic acid and prevention of thrombosis and atherosclerosis. Lancet 1978;i:117-119.

74 Kromann N, Green A: Epidemiological studies in the Upernavik district, Greenland. Acta Med Scand 1980;208:401-406.

-75 Newman WP, Middaugh JP, Propst MT, Rogers DR: Atherosclerosis in Alaska natives and non-natives. Lancet 1993;341:10561057.

-76 Bang HO, Dyerberg J, Hjorne N: The composition of food consumed by Greenland Eskimos. Acta Med Scand 1976;200:69-73.
77 Yano K, MacLean CJ, Reed DM, Shimizu Y, Sasaki H, Kodama K, Kato H, Kagan A: A comparison of the 12-year mortality and predictive factors of coronary heart disease among Japanese men in Japan and Hawaii. Am J Epidemiol 1988;127:476-487.

78 Yuan JM, Ross RK, Gao YT, Yu MC: Fish and shellfish consumption in relation to death from myocardial infarction among men in Shanghai, China. Am J Epidemiol 2001;154: 809-816.

79 Kromhout D, Bosschieter EB, De Lezenne Coulander C: The inverse relation between fish consumption and 20-year mortality from coronary heart disease. N Engl J Med 1985;312:1205-1209.

80 Norell SE, Ahlbom A, Feichting M, Pedersen NL: Fish consumption and mortality from heart disease. Br Med J 1986;283:426.

81 Nordoy A, Goodnight SH: Dietary lipids and thrombosis: relationships to atherosclerosis. Arteriosclerosis 1990;10:149-163.

82 Dolecek TA, Granditis G: Dietary polyunsaturated fatty acids and mortality in the Multiple Risk Factor Intervention Trial (MRFIT). World Rev Nutr Diet 1991;66:205216.

83 Albert CM, Campos H, Stampfer MJ, Ridker PM, Manson JE, Willett WC, Ma J: Blood levels of long-chain $\mathrm{n}-3$ fatty acids and the risk of sudden death. N Engl J Med 2002;346: 1113-1118.

84 Hunter DJ, Kazda I, Chockalingam A, Fodor JG: Fish consumption and cardiovascular mortality in Canada: an inter-regional comparison. Am J Prev Med 1988;4:5-10.

85 Shimokawa H, Vanhoutte PM: Dietary omega-3 fatty acids and endothelium-dependent relaxations in porcine coronary arteries. Am J Physiol 1989;256:H968-H973.

86 Ascherio A, Rimm EB, Stampfer MJ, Giovannucci EL, Willett WC: Dietary intake of marine $\mathrm{n}-3$ fatty acids, fish intake, and the risk of coronary disease among men. $\mathrm{N}$ Engl J Med 1995;332:977-982.

87 Morris MC, Manson JE, Rosner B, Buring JE, Willett WC, Hennekens CH: Fish consumption and cardiovascular disease in the physicians' health study: A prospective study. Am J Epidemiol 1995;142:166-175.

88 De Caterina R, Madonna R, Hassan J, Procopio AD: Nutrients and gene expression. World Rev Nutr Diet 2001;89:23-52.

89 De Caterina R, Zampolli A, Del Turco S, Madonna R, Massaro M: Nutritional mechanisms that influence cardiovascular disease. Am J Clin Nutr 2005; in press.

90 Soei L, Lamers J, Sassen L, van Tol A, Scheek L, Dekkers D, van Meegen J, Verdouw P: Fish oil: A modulator of experimental atherosclerosis in animals; in Kristensen S, Endres S, De Caterina R, Schmidt E (eds): n-3 Fatty Acids: Prevention and Treatment in Vascular Disease. Berlin, Springer, 1995, pp 7784.
91 Eritsland J, Arnesen H, Grønseth K, Field NB, Abdelnoor M: Effect of supplementation with $\mathrm{n}-3$ fatty acids on graft patency in patients undergoing coronary artery bypass operation. Results from the SHOT study. Eur Heart J 1994;15:29.

92 De Caterina R, Cybulsky MI, Clinton SK, Gimbrone MA, Libby P: The omega-3 fatty acid docosahexaenoate reduces cytokineinduced expression of proatherogenic and proinflammatory proteins in human endothelial cells. Arterioscler Thromb Vasc Biol 1994;14:1829-1836.

93 De Caterina R, Bernini W, Carluccio M, Liao J, Libby P: Structural requirements for inhibition of cytokine-induced endothelial activation by unsaturated fatty acids. J Lipid Res 1998;39:1062-1070.

94 Massaro M, Basta G, Lazzerini G, Carluccio M, Bosetti F, Solaini G, Visioli F, Paolicchi A, De Caterina R: Quenching of intracellular ROS generation as a mechanism for oleate-induced reduction of endothelial activation and early atherogenesis. Thromb Haemost 2002;88:176-375.

95 Sethi S, Ziouzenkova O, Ni H, Wagner DD, Plutzky J, Mayadas TN: Oxidized omega-3 fatty acids in fish oil inhibit leukocyte-endothelial interactions through activation of PPAR alpha. Blood 2002;100:1340-1346.

96 Marx N, Duez H, Fruchart JC, Staels B: Peroxisome proliferator-activated receptors and atherogenesis: regulators of gene expression in vascular cells. Circ Res 2004;94: 1168-1178.

97 Issemann I, Green S: Activation of a member of the steroid hormone receptor superfamily by peroxisome proliferators. Nature 1990;347:645-650.

98 Inoue I, Shino K, Noji S, Awata T, Katayama $S$ : Expression of peroxisome proliferatoractivated receptor alpha (PPAR alpha) in primary cultures of human vascular endothelial cells. Biochem Biophys Res Commun 1998;246:370-374.

99 Ziouzenkova O, Plutzky J: Lipolytic PPAR activation: New insights into the intersection of triglycerides and inflammation? Curr Opin Clin Nutr Metab Care 2004;7: 369-375.

100 Wahli W, Braissant O, Desvergne B: Peroxisome proliferator activated receptors: transcriptional regulators of adipogenesis, lipid metabolism and more. Chem Biol 1995;2: 261-266.

101 Desvregne B, Wahli W: Peroxisome proliferator-activated receptor: nuclear control of metabolism. Endocr Rev 1999;20:649688.

102 Tontonoz P, Hu E, Graves RA, Budavari AI Spiegelman BM: mPpar gamma 2: tissuespecific regulator of an adipocyte enhancer. Genes Dev 1994;8:1224-1234. 
103 Braissant O, Foufelle F, Scotto C, Dauca M, Wahli W: Differential expression of peroxisome proliferator-activated receptors (PPARs): tissue distribution of PPAR-alpha, -beta, and -gamma in the adult rat. Endocrinology 1996;137:354-366.

104 Marx N, Sukhova GK, Collins T, Libby P, Plutzky J: PPARalpha activators inhibit cytokine-induced vascular cell adhesion molecule-1 expression in human endothelial cells. Circulation 1999;99:3125-3131.

105 Mishra A, Chaudhary A, Sethi S: Oxidized omega-3 fatty acids inhibit NF-kappaB activation via a PPARalpha-dependent pathway. Arterioscler Thromb Vasc Biol 2004; 24:1621-1627.

106 Thies F, Garry JM, Yaqoob P, Rerkasem K, Williams J, Shearman CP, Gallagher PJ, Calder PC, Grimble RF: Association of n-3 polyunsaturated fatty acids with stability of atherosclerotic plaques: a randomised controlled trial. Lancet 2003;361:477-485.

107 Connolly JM, Gilhooly EM, Rose DP: Effects of reduced dietary linoleic acid intake, alone or combined with an algal source of docosahexaenoic acid, on MDA-MB-231 breast cancer cell growth and apoptosis in nude mice. Nutr Cancer 1999;35:44-49.

108 Rose DP, Connolly JM, Coleman M: Effect of omega-3 fatty acids on the progression of metastases after the surgical excision of human breast cancer cell solid tumors growing in nude mice. Clin Cancer Res 1996;2: 1751-1756.

109 Rose DP, Connolly JM: Antiangiogenicity of docosahexaenoic acid and its role in the suppression of breast cancer cell growth in nude mice. Int J Oncol 1999;15:1011-1015.

110 Suzuki I, Iigo M, Ishikawa C, Kuhara T, Asamoto M, Kunimoto T, Moore MA, Yazawa K, Araki E, Tsuda H: Inhibitory effects of oleic and docosahexaenoic acids on lung metastasis by colon-carcinoma-26 cells are associated with reduced matrix metalloproteinase-2 and -9 activities. Int J Cancer 1997;73:607-612.

111 Harris MA, Hansen RA, Vidsudhiphan P, Koslo JL, Thomas JB, Watkins BA, Allen KG: Effects of conjugated linoleic acids and docosahexaenoic acid on rat liver and reproductive tissue fatty acids, prostaglandins and matrix metalloproteinase production. Prostaglandins Leukot Essent Fatty Acids 2001;65:23-29.

112 Calviello G, Di Nicuolo F, Gragnoli S, Piccioni E, Serini S, Maggiano N, Tringali G, Navarra P, Ranelletti FO, Palozza P: n-3 PUFAs reduce VEGF expression in human colon cancer cells modulating the COX-2/ PGE2 induced ERK-1 and -2 and HIF-1alpha induction pathway. Carcinogenesis 2004;25:2303-2310.
113 Yang SP, Morita I, Murota SI: Eicosapentaenoic acid attenuates vascular endothelial growth factor-induced proliferation via inhibiting Flk-1 receptor expression in bovine carotid artery endothelial cells. J Cell Physiol 1998;176:342-349.

114 Kanayasu T, Morita I, Nakao-Hayashi J, Asuwa N, Fujisawa C, Ishii T, Ito H, Murota $\mathrm{S}$ : Eicosapentaenoic acid inhibits tube formation of vascular endothelial cells in vitro. Lipids 1991;26:271-276.

115 Tsuji M, Murota SI, Morita I: Docosapentaenoic acid (22:5, n-3) suppressed tubeforming activity in endothelial cells induced by vascular endothelial growth factor. Prostaglandins Leukot Essent Fatty Acids 2003;68:337-342.

116 Jones MK, Wang H, Peskar BM, Levin E, Itani RM, Sarfeh IJ, Tarnawski AS: Inhibition of angiogenesis by nonsteroidal antiinflammatory drugs: insight into mechanisms and implications for cancer growth and ulcer healing. Nat Med 1999;5:14181423.

117 Wang LH, Hajibeigi A, Xu XM, LooseMitchell D, Wu KK: Characterization of the promoter of human prostaglandin $\mathrm{H}$ synthase-1 gene. Biochem Biophys Res Commun 1993;190:406-411.

118 Tanabe T, Tohnai N: Cyclooxygenase isozymes and their gene structures and expression. Prostaglandins Other Lipid Mediat 2002;68-69:95-114.

119 Hla T, Neilson K: Human cyclooxygenase-2 cDNA. Proc Natl Acad Sci USA 1992;89: 7384-7388.

120 Ramsay R, Ciznadija M, Vanevski M, Mantamadiotis $\mathrm{T}$ : Transcriptional regulation of cyclo-oxygenase expression: three pillars of control. Int J Immunopathol Pharmacol 2003;16:59-67.

121 Pahl H, Baeuerle PA: Oxygen and the control of gene expression. Bioassays 1994;16: 479-501.

122 Hayden MS, Ghosh S: Signaling to NF-kappaB. Genes Dev 2004;18:2195-2224.

123 Guan Z, Buckman SY, Pentland AP, Templeton DJ, Morrison AR: Induction of cyclooxygenase- 2 by the activated MEKK1 -> SEK1/MKK4 $\rightarrow$ p38 mitogen-activated protein kinase pathway. J Biol Chem 1998; 273:12901-12908.

124 Rikitake Y, Hirata K, Kawashima S, Takeuchi S, Shimokawa Y, Kojima Y, Inoue N, Yokoyama M: Signaling mechanism underlying COX-2 induction by lysophosphatidylcholine. Biochem Biophys Res Commun 2001;281:1291-1297.

125 Hirai K, Ezumi Y, Nishida E, Uchiyama T, Takayama H: Comparative study of vanadate- and phorbol ester-induced cyclo-oxygenase-2 expression in human endothelial cells. Thromb Haemost 1999;82:15451552 .
126 Lee JY, Plakidas A, Lee WH, Heikkinen A, Chanmugam P, Bray G, Hwang DH: Differential modulation of Toll-like receptors by fatty acids: preferential inhibition by $n-3$ polyunsaturated fatty acids. J Lipid Res 2003;44:479-486.

127 Lee JY, Ye J, Gao Z, Youn HS, Lee WH, Zhao L, Sizemore N, Hwang DH: Reciprocal modulation of Toll-like receptor- 4 signaling pathways involving MyD88 and phosphatidylinositol 3-kinase/AKT by saturated and polyunsaturated fatty acids. J Biol Chem 2003;278:37041-37051.

128 Bagga D, Wang L, Farias-Eisner R, Glaspy JA, Reddy ST: Differential effects of prostaglandin derived from omega- 6 and omega3 polyunsaturated fatty acids on COX- 2 expression and IL- 6 secretion. Proc Natl Acad Sci USA 2003;100:1751-1756.

129 Gilbert M, Dalloz S, Maclouf J, Lagarde M: Differential effects of long chain $n-3$ fatty acids on the expression of PGH synthase isoforms in bovine aortic endothelial cells. Prostaglandins Leukot Essent Fatty Acids 1999;60:363-365.

130 Ait-Said F, Elalamy I, Werts C, Gomard MT, Jacquemin C, Couetil JP, Hatmi M: Inhibition by eicosapentaenoic acid of ILlbeta-induced PGHS-2 expression in human microvascular endothelial cells: involvement of lipoxygenase-derived metabolites and p38 MAPK pathway. Biochim Biophys Acta 2003;1631:77-84.

131 Massaro M, Habib A, Lubrano L, Del Turco S, Lazzerini G, Bourcier T, Weksler BB, De Caterina R: The omega-3 fatty acid docosahexaenoate attenuates endothelial cyclooxygenase-2 induction through both NADP $(\mathrm{H})$ oxidase and PKCepsilon inhibition. Proc Natl Acad Sci USA 2006;103: 15184-15189.

132 Cok SJ, Morrison AR: The 3'-untranslated region of murine cyclooxygenase- 2 contains multiple regulatory elements that alter message stability and translational efficiency. J Biol Chem 2001;276:23179-23185.

133 Ma DW, Seo J, Switzer KC, Fan YY, McMurray DN, Lupton JR, Chapkin RS: n-3 PUFA and membrane microdomains: a new frontier in bioactive lipid research. J Nutr Biochem 2004;15:700-706.

134 Stillwell W, Shaikh SR, Zerouga M, Siddiqui R, Wassall SR: Docosahexaenoic acid affects cell signaling by altering lipid rafts. Reprod Nutr Dev 2005;45:559-579.

135 Li Q, Engelhardt JF: Interleukin-1beta induction of NFkappaB is partially regulated by $\mathrm{H}_{2} \mathrm{O}_{2}$-mediated activation of NFkappaB-inducing kinase. J Biol Chem 2006; 281:1495-1505.

136 Ray R, Shah AM: NADPH oxidase and endothelial cell function. Clin Sci (Lond) 2005;109:217-226. 
137 Rueckschloss U, Duerrschmidt N, Morawietz H: NADPH oxidase in endothelial cells: impact on atherosclerosis. Antioxid Redox Signal 2003;5:171-180.

138 Chang MS, Chen BC, Yu MT, Sheu JR, Chen TF, Lin CH: Phorbol 12-myristate 13-acetate upregulates cyclooxygenase- 2 expression in human pulmonary epithelial cells via Ras, Raf-1, ERK, and NF-kappaB, but not p38 MAPK, pathways. Cell Signal 2005; 17:299-310.

139 Li RC, Ping P, Zhang J, Wead WB, Cao X, Gao J, Zheng Y, Huang S, Han J, Bolli R: PKCepsilon modulates NF-kappaB and AP-1 via mitogen-activated protein kinases in adult rabbit cardiomyocytes. Am J Physiol 2000;279:H1679-H1689.
140 Jude S, Roger S, Martel E, Besson P, Richard S, Bougnoux P, Champeroux P, Le Guennec JY: Dietary long-chain omega-3 fatty acids of marine origin: A comparison of their protective effects on coronary heart disease and breast cancers. Prog Biophys Mol Biol 2006;90:299-325.

141 Li JM, Shah AM: Intracellular localization and preassembly of the NADPH oxidase complex in cultured endothelial cells. J Biol Chem 2002;277:19952-19960.

142 Touyz RM, Schiffrin EL: Peroxisome proliferator-activated receptors in vascular biology-molecular mechanisms and clinical implications. Vascul Pharmacol 2006;45: 19-28.
143 Daniel TO, Liu H, Morrow JD, Crews BC, Marnett LJ: Thromboxane A2 is a mediator of cyclooxygenase-2-dependent endothelial migration and angiogenesis. Cancer Res 1999;59:4574-4577.

144 Sakurai S, Alam S, Pagan-Mercado G, Hickman F, Tsai JY, Zelenka P, Sato S: Retinal capillary pericyte proliferation and cFos mRNA induction by prostaglandin D2 through the cAMP response element. Invest Ophthalmol Vis Sci 2002;43:27742781.

145 Ackman RG: Nutritional composition of fats in seafoods. Prog Food Nutr Sci 1989; 13:161-289.

146 Racine RA, Deckelbaum RJ: Sources of the very-long-chain unsaturated omega-3 fatty acids: eicosapentaenoic acid and docosahexaenoic acid. Curr Opin Clin Nutr Metab Care 2007;10:123-128. 